\title{
The Untenable Case for Repeal of Chapter 11
}

\author{
Elizabeth Warren ${ }^{\dagger}$
}

\author{
CONTENTS
}

I. A BRIEF Reprise of the BRADLEY AND RosenzWEIG StUdy . . . . . . 439

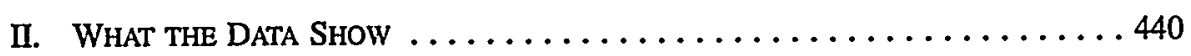

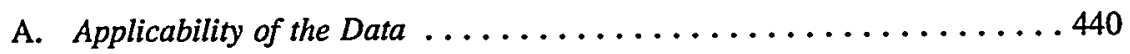

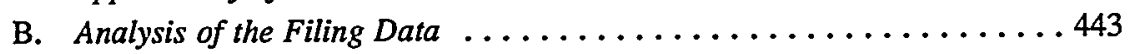

1. The Rise in Bankruptcy Filings ............... 444

2. Testing the Effects of Management Replacement Laws . . . . . 446

C. The Management Incentives Hypothesis . . . . . . . . . . . 448

1. Managerial Control After the Code .............. 449

2. Managerial Control Before the Code ............. 452

D. Data Biases . . . . . . . . . . . . . . . . . 455

E. Multiple Causation ..................... 460

III. Losing VALUE OR RedistRIBUting VALUE? . . . . . . . . . . 467

A. Redistributional Goals of Bankruptcy . . . . . . . . . . . 467

1. Distribution Away From Public Bondholders and Shareholders . . . 468

2. Distribution to Other Affected Parties ............ 470

B. Redistribution in the Perfect Markets Solution ........... 472

C. Comparing Costs of Bankruptcy and "Perfect Markets" . . . . . . . . 474

IV. ConcLusion $\ldots \ldots \ldots \ldots \ldots \ldots \ldots \ldots \ldots \ldots \ldots \ldots \ldots 77$

Bankruptcy policymaking has become a treacherous undertaking. Because bankruptcy law is an integral part of the legal environment in which American companies transact business, significant changes in the laws governing business bankruptcy would have considerable economic impact. Moreover, as business-

† William A. Schnader Professor of Commercial Law, University of Pennsylvania, and Visiting Professor of Law, Harvard University. I wish to thank Kurt Gwynne and Susan Sack, University of Pennsylvania Law School Class of 1992, and Mark Hageman, Harvard Law School Class of 1993, for excellent research assistance. I also wish to thank Daniel Epstein, University of Pennsylvania Law School Class of 1992, for outstanding editorial assistance. 
people have discovered the power of bankruptcy laws, the process of statutory review and readjustment has increasingly taken place under intense pressure from interest groups lobbying for changes that would enhance their positions when businesses fail. As bankruptcy lawmaking has become highly politicized, Congress has repeatedly found itself reexamining a complex set of statutes under conditions that are not optimal for thoughtful reflection.

The obstacles to effective policymaking are compounded by the absence of systematic empirical evidence about how the bankruptcy system operates. The only regular government reports are limited to filing information, and scholarly forays into the field are episodic adventures involving great expense and labor. ${ }^{1}$ With hard data about the bankruptcy system exceedingly scarce, policy debates are often a messy mixture of personal anecdotes, unsupported assertions, and carefully concealed empirical assumptions.

Into this near void came Michael Bradley and Michael Rosenzweig with an extensive analysis of the behavior of certain companies in Chapter $11 .^{2}$ Bradley and Rosenzweig collected data on the performance of these companies in the bond and stock markets in an attempt to confirm their hypothesis that bankruptcy "enhances management's wealth at the expense of corporate security holders."3 On the basis of the evidence they present, they propose the repeal of Chapter 11. In this Article I argue that Bradley and Rosenzweig's study does not support their conclusion that Chapter 11 should be repealed.

I applaud Bradley and Rosenzweig for two reasons: they have developed a testable hypothesis about Chapter 11, and they have assembled data in an effort to confirm their hypothesis. Such an approach makes an important contribution to the ongoing debate about bankruptcy, and reinforces the critical importance of empirical research in this area of the law. This accomplishment should not be underestimated.

Empirical research, however, is fraught with dangers. It is extraordinarily difficult to execute a large, empirical study. Unless the researcher exercises great care, error can multiply throughout the work, rendering the results useless. The empirical researcher must invest a great deal of time away from public view

1. This is not to say that there have not been some extraordinary research efforts. The extensive study of large corporate bankruptcies by LoPucki and Whitford deserves special attention. Lynn M. LoPucki \& William C. Whitford, Bargaining Over Equity's Share in the Bankruptcy Reorganization of Large, Publicly Held Companies, 139 U. PA. L. REv. 125 (1990) (describing extensive study of 43 cases filed after October 1, 1979 with confirmed plans by March 31,1988 ). There has also been a comprehensive study of consumer debtors under the new Code. TERESA SULLIVAN, ELIZABETH WARREN, AND JAY WESTBROOR, AS WE FORGIVE OUR DEBTORS: BANKRUPTCY AND CONSUMER CREDIT IN AMERICA (1989) (analysis based on a sample of 1,557 personal bankruptcy filings from ten judicial districts in 1981). Empirical studies in bankruptcy nevertheless remain scarce. As a consequence, policy debates tend to be conducted with inadequate empirical data. See Teresa Sullivan, Elizabeth Warren, and Jay Westbrook, The Use of Empirical Data in Formulating Bankruptcy Policy, 50 LAW \& CONTEMP. PROBS. 195 (1987) (discussing explanations for the dearth of empirical information in bankruptcy). (1992).

2. Michael Bradley \& Michael Rosenzweig, The Untenable Case for Chapter 11, 101 YALE L.J. 1043

3. Id. at 1049-50. 
to produce data, and the work is unlikely to be replicated, or even challenged, elsewhere. This places a special burden on the researcher to be forthcoming about the limitations of the data and to be cautious in stating conclusions based on the data.

My principal concern is that Bradley and Rosenzweig have not dealt with their data as responsibly as they should have. In the following Part, I offer a brief reprise of their study. In Part II, I reanalyze the data they present, examining the contradictory data they ignore and reviewing the design and execution of their study to expose biases in the data they report. In Part III, I consider the redistributional objectives of the bankruptcy laws, and I argue that Bradley and Rosenzweig's analysis suffers from failure to take these objectives into account. I conclude that the data they present do not demonstrate the validity of the hypothesis they claim to have substantiated.

\section{A BRIEF REPRISE OF THE BRADLEY AND ROSENZWEIG STUDY}

Bradley and Rosenzweig begin their article with the hypothesis that the change in the bankruptcy laws ushered in by the adoption of the 1978 Code has encouraged management misbehavior to the detriment of the creditors and the owners of businesses. ${ }^{4}$ Their central concern is that the Bankruptcy Code ("the Code") permits managers to keep their jobs in situations where they otherwise might not. ${ }^{5}$ As a result, they argue, managers rely on bankruptcy to save them from bad decisions, thereby increasing incentives to involve the company in high risk ventures. Bradley and Rosenzweig posit that job protection for management makes bankruptcy an "endogenous", event-that is, that managers "choose" to lead a company into insolvency by taking on impossibly high debt burdens because they know that they will not personally pay the price for a subsequent failure. To this unique premise, Bradley and Rosenzweig add a second, subsidiary hypothesis: when managers file for bankruptcy, they do not do so to preserve the value of corporate assets in order to save a failing business. ${ }^{8}$ Rather, they do so to "enhance management's wealth at the expense of corporate security holders." Accordingly, they argue, "the principal beneficiaries of Chapter 11 (excluding the legions of lawyers, accountants and financial advisors who earn substantial fees from bankruptcy reorganizations) are corporate managers." 10
4. Id. at 1048 .
5. Id. at 1045 .
6. Id. at 1047 .
7. $I d$.
8. Id. at $1049-50$.
9. Id.
10. Id. at 1049. 
The structure of Bradley and Rosenzweig's argument is as follows: (1) they note a startling rise in business bankruptcy filings after the adoption of the 1978 Bankruptcy Code; (2) they present empirical data about pre- and post-Code bankrupt firms that purportedly show that post-Code filings resulted in greater losses; and (3) they conclude that the rise in filings and the increased losses are due to managerial misbehavior.

Bradley and Rosenzweig conduct their study by examining 162 publicly traded companies that filed for bankruptcy during the 1960's and 1970's, that is, before the new Bankruptcy Code took effect in late 1979, and 162 publicly traded companies that filed for bankruptcy during the 1980's. They assemble stock and bond prices for a subset of these 162 pre- and 162 post-Code filing companies covering periods both before and after their bankruptcy filing. They then compare the stock and bond performance of the companies that filed preCode with similar data for the companies that filed post-Code, and they attribute differences between the two groups to changes in managerial incentives inherent in the new Bankruptcy Code. Their conclusion is that the data "reveal dramatically the extent to which stockholders [and bondholders] have been hurt by the 1978 Act," repeal of Chapter 11.

\section{What the Data SHOW}

The difficulties with Bradley and Rosenzweig's data are numerous, but one problem appears throughout their article: the data do not demonstrate what Bradley and Rosenzweig claim they do. In this section, I examine five major problems with the data: 1 ) the applicability of the data is limited to the cases they studied; 2) the filing data contradict the management incentives hypothesis; 3) other available data contradict the management incentives hypothesis; 4) flaws in the collection of the data bias the sample; and 5) plausible alternative hypotheses may explain many of their statistical findings.

\section{A. Applicability of the Data}

To understand how Chapter 11 has operated under the Code, Bradley and Rosenzweig look at only 162 post-Code Chapter 11 cases-about 16 cases per year. ${ }^{12}$ A sample of 162 cases over an eleven year period is not necessarily

11. Id. at 1068.

12. They also examine 157 pre-Code cases for comparison purposes, $i d$. at 1075 (Table 11). The precise size of the pre-Code sample, however, is unclear. Table 5 presents the total number of pre-Code firms as $163, i d$. at 1065, and Table A.2 in the Appendix indicates 165 total pre-Code filings and only 61 pre-Code filings listed on Compustat, $i d$. at 1092. The reported sample size for post-Code cases is also inconsistent. Bradley and Rosenzweig report a total of 162 post-Code cases at the outset of their article, id. at 1059, a number that is repeated in Table $11, i d$. at 1075 . But that number later climbs to 163 without explanation, id. at 1065 (Table 5), 1092 (Table A.2). 
problematic. If the cases were randomly drawn, they might well represent, within a reasonable error range, the experiences of the bulk of Chapter 11 cases filed during the decade. But the Bradley and Rosenzweig sample is not random. It restricts itself to publicly traded companies, and, moreover, to only those companies for which certain data were available through public sources. ${ }^{13}$ The sample contains none of the private companies that declared bankruptcy.

The impact of this bias in sample selection is significant. In the post-Code period surveyed by Bradley and Rosenzweig, there were 173,108 Chapter 11 filings. ${ }^{14}$ Publicly traded companies represent less than one-tenth of $1 \%$ of all the Chapter 11 cases during that time period ( 0.000936 of the cases). ${ }^{15}$ Indeed, if a random sample of 162 Chapter 11 cases had been drawn, the odds of picking even one case involving a publicly traded company would be very small. ${ }^{16}$ Bradley and Rosenzweig thus diagnose a problem and propose a solution that purports to be applicable to all Chapter 11 cases based on their analysis of a highly selective sample.

Bradley and Rosenzweig are not unaware of this difficulty. Nowhere do they misrepresent their data or suggest that their sample was randomly drawn. Indeed, thirty-four pages into their forty-six page article, they acknowledge the problem in a footnote: "Our data, of course, are also limited to public corporations. We therefore make no empirical case against Chapter 11 insofar at it applies to nonpublic corporations. ... [O]ne might conclude that our proposal to abolish court-supervised corporate reorganization should be limited to public companies. . .."17 In the same footnote, however, Bradley and Rosenzweig go on to defend their sweeping indictment of Chapter 11, maintaining that their "theoretical analysis of corporate reorganization, particularly [the] discussion of management-creditor conflicts, arguably applies with equal force to private companies."18

13. Bradley and Rosenzweig exclude data on the bankruptcies of public companies that did not appear in Compustat trading records during the months surrounding the bankruptcy filing, and data on the bankruptcies of publicly traded companies that were not discussed in the pages of the Wall Street Journal. This means that their sample omits a certain number of publicly traded companies. I address the possible impact of this omission on Bradley and Rosenzweig's findings infra text accompanying notes 80-95. For the moment, however, I ignore this complication and assume arguendo that the sample includes all publicly traded companies that filed for bankruptcy in the relevant periods.

14. Bradley \& Rosenzweig, supra note 2 , at 1090 . The figure was obtained by summing the column marked "total" from 1980 through 1989 in Table A.1.

15. The calculation is based on Bradley and Rosenzweig's reported data. And although the sample omits a certain proportion of the filings of publicly traded cases, see supra note 13, it is nevertheless clear that the bankruptcies of publicly traded companies constitute only a tiny fraction of $1 \%$ of all Chapter 11 filings.

16. The odds of picking one company or more from the Bradley and Rosenzweig sample in a random sample of 162 Chapter 11 cases from the same time period are about 1 in 7 . The odds of picking at least two cases from the Bradley and Rosenzweig sample are about 1 in 100.

17. Bradley \& Rosenzweig, supra note 2, at $1077 \mathrm{n} .80$.

18. $l d$. at $1078 \mathrm{n} .80$. Bradley and Rosenzweig argue that the burden is on their critics to prove that their hypothesis does not hold beyond the limits of the evidence they present, as well as to demonstrate that their policy recommendations are not as appropriate to private as they are to public companies. $I d$. 
There are a number of reasons why the management strategies of a momand-pop grocery, a separately incorporated apartment complex, a four-state trucking concern, a family owned construction company, a tax-driven real estate investment trust, a single employee professional corporation, and a manufacturing subsidiary of a large lumber mill might differ from the management strategies of Johns Manville, LTV Steel, or Eastern Airlines. The close link between residual ownership and management in smaller businesses sets managerial decisionmaking in that context apart from decisionmaking in larger cases where management often has little in common with shareholders. This makes Bradley and Rosenzweig's assertion that bankruptcy "enhances management's wealth at the expense of corporate security holders" nonsensical in most Chapter 11's, since managers and shareholders are often the same people. ${ }^{19}$

Not only do management incentives differ, but the dynamics of reorganization of large publicly traded companies may differ from those of their smaller, private counterparts, and these differences may influence the decision to file for bankruptcy. A larger company, for example can hire a team of lawyers to advise it about the relative merits of a bankruptcy filing long before it faces a foreclosure action or withdrawal of a line of credit. It can also count on a large management structure to leave some people in charge of the business while others deal with the renegotiation of debt. These are luxuries unavailable to the smaller company in trouble. At the same time, the complexity of a reorganization may grow exponentially with the size of the business, and thus the difficulties of managing a multinational corporation with hundreds of thousands of creditors, balking unions, unhappy government regulators, disgruntled pensioners, and a long cast of other players making heated demands, may make it more expensive and more difficult for large companies to reorganize.

Creditors of large and small companies may be different as well. The largest companies may have a disproportionately greater number of problems with disgruntled unions, government regulators, and angry pensioners. The relatively greater sophistication of very large lenders may also make debt renegotiation proceed differently for large companies than it would for small companies, which deal with local creditors. Because the latter generally play a less active role in

19. Bradley and Rosenzweig acknowledge in their one footnote on the subject that "the separation of ownership from control that characterizes public companies is often absent (or at least less pronounced) in private firms." Id. They argue, however, that the managers of these firms still seek Chapter 11 to avoid having their creditors take control of the business. The scholarly literature about management incentives demonstrates a number of ways in which the managers of public and private companies behave differently, and it counters the hypothesis that the structure of managerial incentives in one context can be assumed to apply to different contexts. See, e.g., H.N. BROOM AND JUSTnN G. LONGNECKER, SMALL BUSINESS MANAGEMENT (3d ed. 1971) (discussing differences between managerial incentives, techniques, and opportunities in large and small companies); DAVD S. BROWN, MANAGING THE LARGE ORGANIZATION: ISSUES, IDEAS, PRECEPTS, INNOVATIONS (1982) (same); MANAGING THE SMALlER COMPANY (Russell Banks ed., 1969); Janet Bamard, Getting Strategic Planning Off the Ground, 39 MANAGE 9 (1986) (discussing decisionmaking and credit strategies among small businesses); Kathleen Melymuka, Working to Scale, 5 CIO 36 (1992) (discussing the special economic constraints placed on small businesses in a recession). 
a reorganization effort, smaller businesses encounter less supervision from their creditors after bankruptcy. This may encourage the U.S. Trustee to take a more active role, which once again serves to set the Chapter 11 experience for small businesses apart from those of their larger counterparts.

Even in the absence of these structural distinctions, the data suggest a critical difference between the bankruptcy experiences of private and public corporations. Over the past two decades, the filing rates for all corporate bankruptcies have risen by $2,000 \%$, while the filing rates for publicly traded companies have remained steady ${ }^{20}$ The fate of these cases once they are in Chapter 11 also differs markedly. Only about $17 \%$ of all Chapter 11 cases manage to confirm a plan of reorganization, while nearly $90 \%$ of publicly traded companies survive to confirm a plan. ${ }^{21}$ In addition, consolidations resulting in multiple debtor entities (and entailing complicated multiple creditor relationships) are far more common in large cases than in their smaller counterparts. Nearly $70 \%$ of the cases involving assets in excess of $\$ 100$ million (which make up the bulk of the publicly traded companies in bankruptcy), for example, are consolidations of multiple cases, while fewer than $7 \%$ of the cases involving assets of less than $\$ 100,000$ (that is, all private cases) are consolidations. ${ }^{22}$ Chapter 11 repayments also differ as a function of size, with larger cases paying a proportionately larger share of their outstanding debts. ${ }^{23}$ By every statistical measure available, then, the experience of large, publicly traded companies in bankruptcy differs sharply from that of smaller, private companies, and this casts serious doubt on Bradley and Rosenzweig's claim that their data apply with equal force to all corporations choosing Chapter 11.

\section{B. Analysis of the Filing Data}

Despite the fact that Bradley and Rosenzweig do not produce data that permit valid inferences to be drawn about Chapter 11 cases generally, their study would still be useful if it produced reliable data about the bankruptcies of publicly traded companies. They could, in this case, simply limit their conclusions to publicly traded companies. In the next four Sections, I review their data to

20. Calculation from data on corporate filings reported in ANNUAL REPORT OF THE ADMINISTRATIVE OFFICE OF THE UNITED STATES COURTS (1960, 1989). Filings rose from 867 in FY 1969 to 17,447 in FY 1989. The filing data for all corporate bankruptcies can be used as a proxy for nonpublic corporations, since 99.9\% of Chapter 11's are filed by nonpublic companies.

21. ED FLYNN, ADMINISTRATTVE OFFICE OF THE U.S. COURTS, STATISTICAL ANALYSIS OF CHAPTER 11, at 10-11 (1989) (estimating a 17\% confirmation rate for all Chapter 11 filings); Lynn M. LoPucki \& William C. Whitford, Venue Choice and Forum Shopping in the Bankruptcy Reorganization of Large, Publicly Held Companies, 1991 WIS. L. REV. 411, 441 n.105 (finding confirmation rate of 89-96\% among biggest cases filed during 1979-88). Both Flynn and LoPucki and Whitford specifically identify size as a critical variable in the Chapter 11 experience, and they identify a number of ways in which small and large Chapter 11 cases differ in operation. Id.; see also LoPucki \& Whitford, supra note 1, passim.

22. FLYNN, supra note 21 , at 15 (Table $11 \mathrm{~A}$ ).

23. Id. at 16. 
consider what they might say about the failures of publicly traded companies, with the running caveat that the applicability of any findings for privately held companies awaits another study.

\section{The Rise in Bankruptcy Filings}

Bradley and Rosenzweig begin their argument for the hypothesis of managerial misbehavior by documenting a precipitous rise in post-Code corporate filings. They produce the following graph (Figure 1): ${ }^{24}$

\section{FIGURE 1: Graph Offered by Bradley and Rosenzweig to Demonstrate Rise in Bankruptcy Filings}

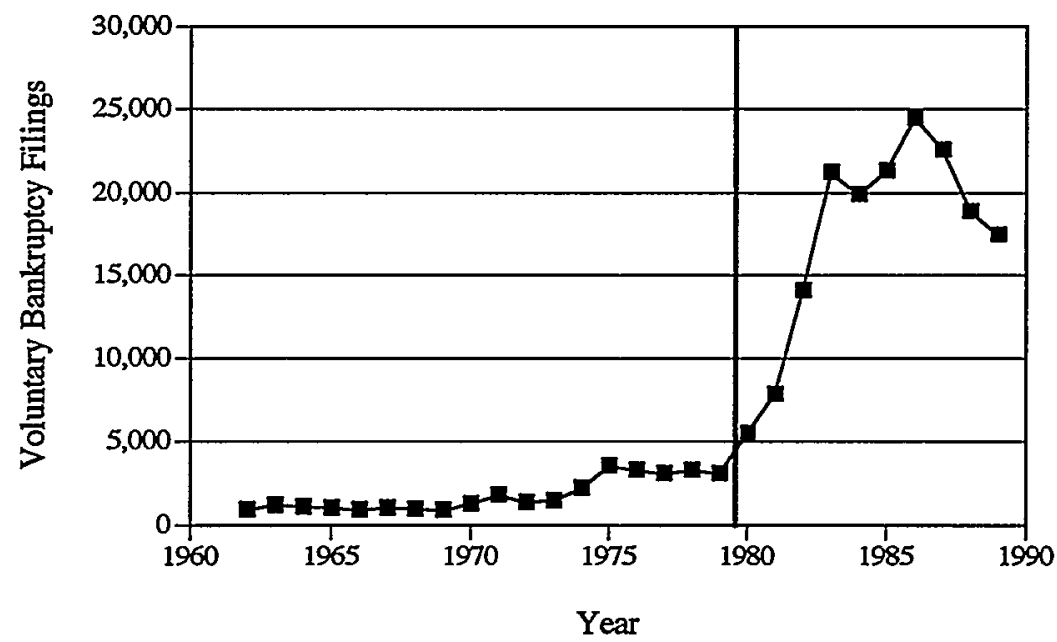

The problem is that Figure 1 is based on all Chapter 11 filings, while all of Bradley and Rosenzweig's other data are limited to publicly traded companies. ${ }^{25}$ They therefore switch data bases between steps one and two of their argument. The financial data on public companies reported in their Tables 2 through 11 cannot be used to eliminate any alternative hypotheses about the rise in all business filings, any more than one could use evidence about a rare

24. Bradley \& Rosenzweig, supra note 2, at 1059 (Figure 1).

25. There are also some individual debtors interspersed throughout these data, since Chapter 11 is open to individuals. The number is small because most debtors find reorganization in Chapter 13 preferable because of its lower cost and increased debtor control. Chapter 13 is available only to individuals, not corporations, and its use is limited to debtors with unsecured debts less than $\$ 100,000$ and secured debts under $\$ 350,000$. 11 U.S.C. $\$ 109$ (a), (e) (1988). Thus, there are very few individuals in Chapter 11, and those that are tend to have very high debt levels. 
breed of roses to eliminate alternative hypotheses about the growth of all flowers. ${ }^{26}$ Bradley and Rosenzweig have not produced a consistent data base even for the publicly traded cases on which they focus.

This error can be cured if comparable data bases are used to explore alternative economic explanations. It is possible to examine differences between pre- and post-Code filings for publicly traded companies-the first step in their argument-and then to use the Bradley and Rosenzweig data about those companies to try to eliminate alternative hypotheses that might explain the postCode rise in filings. While analytically sound, this approach does not serve Bradley and Rosenzweig's purposes well, however, because it disproves their hypothesis.

Bradley and Rosenzweig report that the filing rates for publicly traded companies rose during the period in which the total number of Chapter 11 filings rose precipitously. Although they concede that the data "display no dramatic jump after 1979,"27 they state that "the average number of filings for listed firms does increase from ten per year before 1979 to more than sixteen in the ten years thereafter, and this difference is statistically significant." ${ }^{28}$ The fact that statistical significance in no way ensures substantive significance aside, ${ }^{29}$ this way of reporting the data obscures some highly relevant information. As we learn in a footnote, the only reason Bradley and Rosenzweig are able to report a statistically significant difference between the period "before 1979" and the "ten years thereafter" is that the former period reaches back to include data from the 1960 's, when the filing rates were quite low. ${ }^{30}$ When the number of filings by publicly traded companies in the 1970's alone is compared with the number during the "ten years thereafter," there is no statistically significant difference. ${ }^{31}$

If Bradley and Rosenzweig had stuck with the same data set throughout their analysis of filing rates, Figure 1 would have looked like this:

26. Bradley and Rosenzweig mix data from all Chapter 11 cases with data on publicly traded Chapter 11 cases. In their discussion of survival rates of companies in bankruptcy, for example, they include data on the low failure rates for small Chapter 11 cases to support their conclusions about the failure rates for publicly traded Chapter 11 cases. Id. at $1075 \&$ n.75. This is a serious mistake, since the data strongly suggest that success rates differ sharply between the two groups. As both Flynn and LoPucki \& Whitford have demonstrated, ability to confirm a plan is in part a function of the size of the case. See supra note 21 .

27. Bradley \& Rosenzweig, supra note 2, at 1060.

28. Id. at 1060 (citations omitted).

29. Statistical significance merely establishes the likelihood that if another sample were drawn, analysis of those data would produce a similar result. It does not indicate whether the result has any substantive import.

30. Bradley \& Rosenzweig, supra note 2, at 1060 n.51.

31. Id. 
FIGURE 2: Actual Bankruptcy Filings Based on Bradley and Rosenzweig's Data

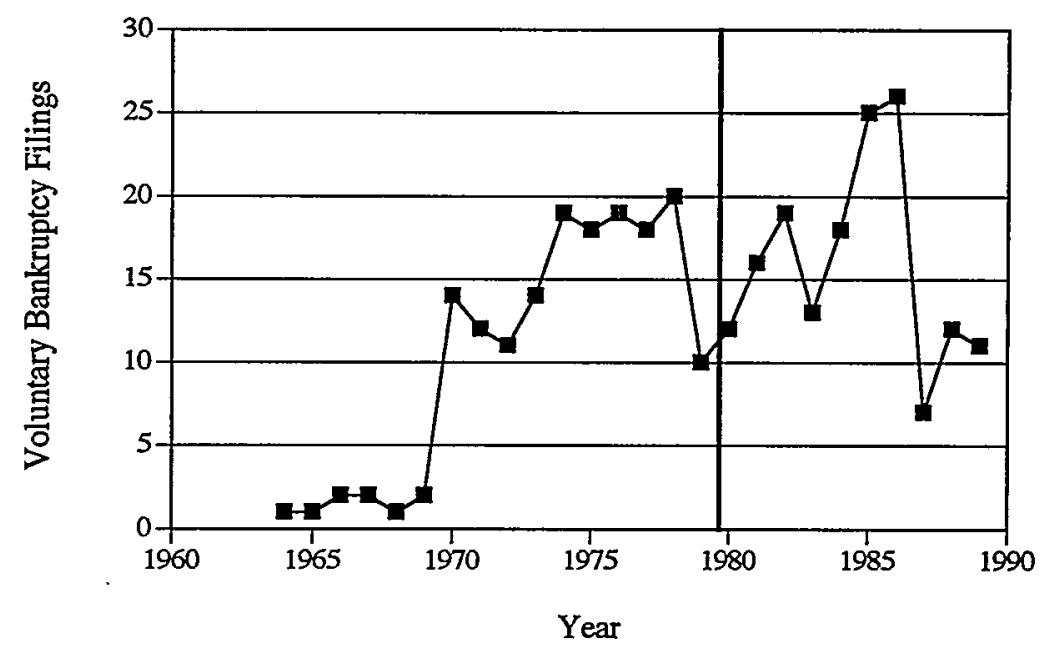

The distinction is critical. Bradley and Rosenzweig use the rise in filing rates after the enactment of the 1978 Code as the first step in their argument, but a comparison of the decade before the Code was enacted with the decade after the Code was enacted shows no difference in filing behavior. These data, therefore, do not support their claim that "the decision to file a bankruptcy petition has become more endogenous under the 1978 Act. ${ }^{32}$ Instead, the data support the opposite conclusion: passage of the 1978 Code had no discernible effect on the bankruptcy filings of publicly traded companies.

\section{Testing the Effects of Management Replacement Laws}

Bradley and Rosenzweig's data furnish other indications that their management control hypothesis is incorrect, even with respect to the publicly traded corporations for which they have gathered data. They argue that the increase in filings from pre-Code to post-Code demonstrates that the change in law permitting management to remain in place during reorganization has resulted in management misbehavior. ${ }^{33}$ Presumably, then, they would accept the converse as true: an absence of change in the number of filings following a

32. Id. at 1076 .

33. Id. ("[T]here has been an overwhelming increase in the number of bankruptcy filings since this legislation became effective. ... We conclude that under the Act, managerial discretion is more significant, and poor financial performance less significant, in determining whether a firm is likely to seek bankruptcy protection."). 
change in the law would suggest that the law produced no management misbehavior. The data are available to make this comparison.

Pre-Code law governing the management of publicly traded companies differed sharply from post-Code law. Before 1979, a publicly traded company filing for bankruptcy was subject to the risk that the case would be converted into Chapter X, which required the appointment of a trustee. ${ }^{34}$ The 1978 Code provided for current management to remain in place, dropping the requirement that a trustee be appointed. ${ }^{35}$ But for private companies, there was no corresponding change in the law. Privately-held companies both pre- and postCode operated under the presumption that current management would remain in control. ${ }^{36}$

The change between pre- and post-Code law for the publicly traded companies and the similarity of pre- and post-Code law for private companies sets up a natural experiment. If changes in the law pertaining to management control have had a profound effect on management decisions, as Bradley and Rosenzweig assert, and if increased filings reflect these changes, as they also assert, then we would expect to see a relatively smaller increase in filings from pre- to post-Code among private companies and a relatively larger increase among publicly traded companies. In other words, if Bradley and Rosenzweig are right, the nonpublic filings should remain relatively stable throughout the period from 1970 to 1990 , while the filings for publicly traded companies should rise rapidly. The data, however, indicate precisely the reverse.

According to Bradley and Rosenzweig's own Figure 1, corporate filings showed an astonishing rise immediately after the new Code was passed. ${ }^{37}$ As Figure 2 shows, during the same time period, filings for publicly traded companies show a rise ten years before the Code was enacted and virtually no change from the decade before enactment to the decade after enactment. These data demonstrate that the rise in bankruptcy filings for public companies bears no discernible relationship to changes in the law concerning managerial control..$^{38}$

34. 11 U.S.C. § 556 (1970) (repealed effective October 1, 1979).

35. 11 U.S.C. $\$ \$ 1104,1107$ (1988). The practice of courts' appointing receivers sua sponte also ended. Such practices were evidently quite diverse around the country and varied even from judge to judge. The new Code added $\$ 105(b)$ partly in response to this problem.

36. Compare 11 U.S.C. $\S \S 342,343$ (1970) (repealed effective October 1, 1979) with 11 U.S.C. §§ 1104, 1107 (1988).

37. Bradley \& Rosenzweig, supra note 2, at 1059.

38. It is not strictly accurate to say that the data show no relationship between the changes in the law regarding managerial control and filing rates. They demonstrate, instead, an inverse relationship: bankruptcy filing rates rise when there is no change in managerial control and remain steady when managerial control is increased. This statement is a correct summary of the statistics, but to the extent that it suggests any kind of causal relationship between one small aspect of the law and bankruptcy filings, it is probably irrelevant. Nonetheless, it demonstrates the danger of basing causal presumptions on such thin empirical foundations. 


\section{The Management Incentives Hypothesis}

A number of scholars have inquired into the question of incentives and the potential for management misbehavior when a company is in financial distress. ${ }^{39}$ Most researchers observe that managers try to avoid financial trouble for their firms, and that bankruptcy is a particularly unwelcome event. ${ }^{40}$

Bradley and Rosenzweig explain their radically different model of managerial decisionmaking: ${ }^{41}$

[F]irms can choose to become "insolvent" by not maintaining a sufficient balance of [liquid] assets. As long as there is a possibility of courtsupervised reorganization, corporate managers have no real incentive to maintain an "adequate" balance. More fundamentally, fashioning a firm's capital structure obviously involves certain choices regarding the use of debt financing. To the extent that managers, influenced by the availability of bankruptcy protection, choose to burden their firms with "too much" debt or "impossible" debt-payment obligations, financial distress is hardly an entirely exogenous event. On this view, corporate bankruptcy frequently is significantly endogenous, chosen by, rather than imposed upon, corporate managers. ${ }^{42}$

The Bradley and Rosenzweig model pictures managers around the country reading the newly passed 1978 Code, swiveling back in their chairs, and giggling with delight: "Now that we have bankruptcy laws that will leave us in charge, we're gonna get wild with this business. If it flops, we'll just take it out of the hide of the creditors and the shareholders, and Chapter 11 will save us!'43

Given some of the high risk decisions that corporate managers made during the 1980's, the model is not without some superficial appeal. On further examination, however, it proves less than satisfactory. It hypothesizes a

39. See, e.g., Douglas Baird \& Thomas Jackson, Bargaining After the Fall and the Contours of the Absolute Priority Rule, 55 U. CHI. L. REV. 738 (1988) (arguing that management and priority creditors have incentives to work together to squeeze out lower priority creditors in a bankruptcy reorganization); Elizabeth Warren, A Theory of Absolute Priority, 1991 N.Y.U. ANN. SURV. AM. L. 9 (1991) (arguing that management of companies in bankruptcy may attempt to capture value of firm for their own purposes rather than for those of the creditors or shareholders of estate).

40. See, e.g., Susan Rose-Ackerman, Risk Taking and Ruin: Bankruptcy and Investment Choice, 22 J. LEGAL STUD. 277 (1991) ("Managers seek to avoid leading their firms into financial difficulties. Bankruptcy is particularly to be avoided.").

41. Bradley and Rosenzweig note the divergence of their view of management misbehavior with that of other bankruptcy scholars. Bradley \& Rosenzweig, supra note 2, at 1045-46.

42. Id. at 1047 (citations omitted).

43. Interestingly, Bradley and Rosenzweig never explain why management would want to begin high risk operations in the first place. As they present it, the model simply presumes that if management could reduce the cost to itself of high risk strategies it would adopt them. But they do not explain what the benefit to management of such high risk strategies would be. This is a troubling omission in light of other research that supports a contrary conclusion. See, e.g., Irwin Friend \& Larry H.P. Lang, An Empirical Test of the Impact of Managerial Self-Interest on Corporate Capital Structure, 43 J. FIN. 271 (1988) (discussing problem of management's "maintaining a low debt ratio to avoid bankruptcy possibility" even when higher debt would be in shareholder's interest). 
managerial cohort that combines uncanny sensitivity to the nuances of legal change with astonishing myopia about what really happens when companies file for bankruptcy.

For the argument from incentives to succeed, it would have to be the case that the allure of court-supervised reorganization is so powerful that it encourages managers to make risky business decisions they would otherwise not make and to choose bankruptcy filings over nonbankruptcy alternatives once that risk materializes. Bradley and Rosenzweig advance no direct evidence to support such a hypothesis; they offer only bits and pieces of financial data from which they assert an inference of management misbehavior can be drawn indirectly. At the same time, they ignore a wealth of data that bear directly on management incentives, data that are inconsistent with their hypothesis.

\section{Managerial Control After the Code}

Bradley and Rosenzweig assert that "Chapter 11, far from preserving valuable assets, in fact serves mainly to protect managers' jobs." ${ }^{\$ 4}$ This hypothesis has been tested by Stuart Gilson, who conducted a careful study of 409 of the most financially troubled publicly traded companies from 1979 through $1984 .{ }^{45}$ In the companies that filed for bankruptcy, managers lost their jobs within two years following filing in $71 \%$ of the cases. ${ }^{46}$ Managers who arranged out-of-bankruptcy debt restructuring for their troubled companies did somewhat better, but $60 \%$ had been replaced within two years of the restructuring. ${ }^{47}$ The replacement rates of management for companies not in financial distress for a comparable two-year period was about $6-10 \% .^{48}$

44. Michael Bradley \& Michael Rosenzweig, Time to Scuttle Chapter II, N.Y. TMES, Mar. 8, 1992 at A13 [hereinafter N.Y. TMMES FORUM]. Bradley and Rosenzweig use the language of economics to make the same point in their piece in the Yale Law Journal. They describe managers as "the ultimate residual claimant[s]" in bankruptcy. Bradley \& Rosenzweig, supra note 2, at 1051 . They explain that managers "expropriate for themselves the wealth of both bondholders and stockholders." Id. at 1052. They propose a solution that they describe as "a realignment of management's incentives that ensures that those in control of the firm would suffer the consequences and enjoy the benefits of their decisions." Id. at $1080 \mathrm{n.85}$.

45. Stuart C. Gilson, Management Turnover and Financial Distress, 25 J. FIN. ECON. 241 (1989).

46. Id. at 247 (Table 3).

47. Id.

48. Sheila Puffer \& Joseph Weintrop, Corporate Performance and CEO Turnover: The Role of Performance Expectations, 36 ADMIN. SCI. Q. 1, 6-7 (1991) (reporting mean annualized turnover rate of $5.3 \%$ for 480 large publicly traded companies on NYSE or AMEX); Michael Weisbach, Outside Directors and CEO Turnover, 20 J. FIN. ECON. 431, 438-41 (1988) (reporting mean annualized turnover rate of 3-5\% for 367 firms listed on Fortune 500 list for 1974-83). Both studies exclude turnovers due to retirements in their calculations, which renders the data comparable to the data on management replacements for troubled businesses. LoPucki and Whitford found that voluntary retirements once the business was in trouble were extremely rare. Lynn M. LoPucki \& William C. Whitford, Corporate Governance in the Bankruptcy Reorganization of Large, Publicly Held Companies, 141 U. PA. L. REV. (forthcoming Dec. 1992) (manuscript at $63-65$, on file with author). When retirement data are included in turnover rates, the rates generally double to about $10-12 \%$, but they remain far below the tumover rates for troubled businesses. John L. Fizel \& Kenneth K.T. Louie, CEO Retention, Firm Performance and Corporate Governance, 11 MANAGERIAL \& DECISION ECON. 167, 169 (1990) (reporting 10\% replacement rate based on study of 706 CEO's in 1984-85); Jerold Warner et al., Stock Prices and Top Management Changes, 20 J. FIN. ECON. 461, 467-69 (1988) 
LoPucki and Whitford studied a somewhat different sample of companies in bankruptcy, focusing on those publicly traded companies that were successful in confirming a plan of reorganization under Chapter 11. They found even higher turnover rates, at least among these companies' CEO's. ${ }^{49}$ During the two-year period beginning eighteen months before the bankruptcy filing and ending six months after the plan confirmations, $91 \%$ of these companies changed CEO's at least once. ${ }^{50}$ LoPucki and Whitford describe the "vast majority" of the turnovers as "involuntary." 51

Yet another study confirms the gloomy prospect for managers of distressed companies. Brian Betker examined management turnover for 202 publicly traded companies that filed for Chapter 11 , and discovered that only $8 \%$ of the top managers who held office two years before filing retained their positions one year after confirmation of the reorganization plan. ${ }^{52}$

The replaced managers in the financially troubled companies were young enough to look forward to many years of occupying the chief corporate office, but they did not simply hop to greener pastures when their companies began to fail..$^{33}$ Not one manager in Gilson's sample was employed in another exchange-listed company any time during the three years following the manager's departure. The loss in personal earnings, Gilson speculates, amounted to a present value of about $\$ 1.3$ million for each manager..$^{54}$

The loss to self-esteem is harder to quantify, but Gilson notes that one of the managers in the study committed suicide when his company's creditors would not go along with his plan to keep the company out of "hostile hands." "55 This observation is consistent with earlier work demonstrating that managers suffer substantial losses in reputation and self-esteem when their companies fail ${ }^{56}$ and with experimental studies showing that when asked to make decisions with a range of outcomes, subjects are particularly loathe to select options that have even a small chance of resulting in financial ruin. ${ }^{57}$ Other studies have docu-

(reporting mean annual turnover of 0.12 changes per firm for random sample of 269 NYSE- and AMEX-listed firms from 1962-80).

49. LoPucki \& Whitford, supra note 1, at 126-27.

50. LoPucki \& Whitford, supra note 48 , at 63 .

51. Id, at 65 .

52. Brian L. Betker, Management Changes, Equity's Bargaining Power and Deviations from Absolute Priority in Chapter 11 Bankruptcies, 11 (Mar. 1992) (unpublished manuscript, on file with author).

53. Gilson, supra note 45 , at $252,255$.

54. Id. at 254 .

55. Id. at 252 .

56. Robert I. Sutton \& Anita L. Callahan, The Stigma of Bankruptcy: Spoiled Organizational Image and Its Management, 30 ACAD. MGMT. J. 405 (1987).

57. Robert Libby \& Peter C. Fishburn, Behavior Models of Risk Taking in Business Decisions: A Survey and Evaluation, 15 J. ACCT. RES. 272, 287-89 (1977). The formal studies are themselves consistent with popular perceptions. While articles appear in the press touting the advantages of a Chapter 11 for a company's profitability, at least as many show the extraordinary difficulty of running a business in Chapter 11. Based on his experience with the reorganization of his own company as well as on those of others, one manager wrote:

Several months after filing every key executive in our firm was sick. ... 
mented management's aversion to filing bankruptcy, even when a company is in serious trouble. ${ }^{58}$

Bradley and Rosenzweig in fact provide data that tend to support the findings of the above-mentioned studies. They note that in the cases they studied, $16.7 \%$ of the publicly traded companies that filed for bankruptcy after the Code was adopted had been delisted from their exchanges within two years of filing, and that $38.3 \%$ had been delisted within four years of filing. ${ }^{59}$ These failure rates would have come as no surprise to management. In the years before the Code was adopted, the two-year delisting rate for publicly traded companies filing for bankruptcy was $25.5 \%$, and the four-year rate was $40.8 \%{ }^{60}$ Management has had over thirty years to learn that Chapter 11 is a high risk proposition. The point should be clear enough to any manager who is not in a coma: managers that operate a company in a way that risks a Chapter 11 filing also run a substantial risk that within a few years of filing there will be no firm for them to manage, and that, even if the firm survives, they will no longer be carrying the keys to the executive washroom. ${ }^{61}$

While the data show that Chapter 11 is highly problematic for managers of publicly traded companies today, it is still conceivable that the disincentives to file for bankruptcy have, on the whole, diminished in the past decade. As a number of commentators have noted, bankruptcy is no longer the corporate equivalent of a dreaded social disease. The stigma associated with Chapter 11 has undoubtedly declined, and the increasing success rates of publicly traded companies filing for bankruptcy should provide some hope for managers of troubled corporations. Nonetheless, it is one thing to note that management may now be more inclined to accept bankruptcy as a means of trying to save a failing company; ${ }^{62}$ it is another thing to contend, as Bradley and Rosenzweig do, that

It doesn't make the judge sick. It doesn't make the lawyers sick. It makes the executives sick.

It is said that in smaller businesses the personal effects of Chapter 11 are greater. But that's based on the assumption that people who run large corporations are insensitive to humiliation and to the stigma that attaches to bankruptcy. In a country known for businessmen who strive to succeed, the role of overseeing a process that is characterized as failure is very hard to take at any size or level, especially when the formerly efficient executive watches the unnecessary prolongation of the Chapter 11 process.

What is common to almost all executives in every industry and in every size of company that finds itself in Chapter 11 is that they are no longer in control of their lives. . . . SOL STEN, A FEAST FOR LAWYERS INSIDE CHAPTER 11: AN EXPOSE 36 (1989).

58. See Friend \& Lang, supra note 43.

59. Bradley \& Rosenzweig, supra note 2, at 1075 (Table 11).

60. Id.

61. I should note that neither the high failure rates of the companies nor the fact that managers are likely to be replaced in bankruptcy implies that Chapter 11 does not work. It only means that Chapter 11 cannot save every company that uses it, and that managers who are only looking out for their own interests would not regard it as a very attractive option.

62. Bradley and Rosenzweig cite a number of commentators who discuss the decline in stigma and the greater effectiveness of Chapter 11 to further their argument that managers follow risk-enhancing strategies because of bankruptcy rather than restructure a troubled firm. Bradley \& Rosenzweig, supra note 2, at 1047-48 n.20. But their conclusion is not supported by the commentators. I was surprised to see my own work cited 
management affirmatively embraces bankruptcy and plans more high risk business activities than it otherwise would because of the protection available in Chapter 11.

In a footnote, Bradley and Rosenzweig acknowledge some of the contradictory evidence, although they do not address the most significant findings-Gilson's data showing a 71\% turnover rate, Betker's data showing a 91\% turnover rate, and LoPucki and Whitford's data showing a 91\% turnover rate. They argue instead that data of this sort are irrelevant to their model: "[W] hat matters is not the particular identity of the managers running the firm in bankruptcy reorganization, but rather the latitude (and incentive) these managers have under Chapter 11 to pursue suboptimal strategies." er, presupposes an improbable model of human behavior. The data show that managers of public companies that file for Chapter 11 face the loss of their jobs, their reputations, their self-esteem, and their incomes. In their assertion that the "particular identity" of a company's managers does not "matter" to incumbent management, Bradley and Rosenzweig seem to suggest that incentive structures are primarily abstract and that individuals do not take their personal well-being into account when they decide how to behave. Moreover, the claim that such factors are irrelevant contradicts their repeated assertion that Chapter 11 "serves mainly to protect managers' jobs. ${ }^{\prime 64}$

\section{Managerial Control Before the Code}

As I noted in the last section, the high management replacement rates for bankrupt companies since the adoption of the Code contradicts the hypothesis that Chapter 11 saves management jobs. It is still possible, however, that the point about changing incentives is valid: if pre-Code replacement rates were even higher, so that the adoption of the 1978 Code lowered the rate of management job loss, then the claim that the increase in filings is due to increased management control is still open for consideration. But the converse must also be true: if management turnover rates were lower before 1978 and rose with

for the proposition that it is "anachronistic" to think of corporate bankruptcy as "a largely exogenous phenomenon." Id. In fact, the cited material is a chapter entitled "New Uses for Business Bankruptcy" that discusses a "variety of factors [that] have made consideration of Chapter 11 a thinkable alternative for businesses with financial difficulties." ELIZABETH WARREN \& JAY L. WESTBROOR, THE LAW OF DEBTORS AND CREDITORS 669-96(1986). Nowhere in this text do we suggest that managers will follow risky strategies because bankruptcy will save them. Instead, we argue that managers will consider bankruptcy as a possible solution to the serious financial problems they encounter. We regarded this point as sufficiently important that we retained it in the second edition of the book, despite the fact that we substantially rewrote the chapter in which it appeared in the earlier edition. ELZABETH WARREN \& JAY L. WESTBROOK, THE LAW OF DEBTORS AND CREDTTORS 745-89 (2d ed. 1991) [hereinafter WARREN \& WESTBROOK, DEBTORS AND CREDITORS].

63. Bradley \& Rosenzweig, supra note 2 , at 1077 n.77.

64. Bradley \& Rosenzweig, N.Y. TMMES FORUM, supra note 44, at A13; see also Bradley \& Rosenzweig, supra note 2, at 1045, 1049, 1050-51, 1075. 
the adoption of the new Code, then the hypothesis that the new laws increased incentives for managers to misbehave is directly contradicted.

I am aware of only two studies of replacement rates for managers of publicly traded companies that filed for bankruptcy during the pre-Code years. One, a study of eleven railroad bankruptcies from 1933 to 1955, shows an annual CEO turnover rate of $8 \%{ }^{65}$ The comparable turnover rate for railroads not in bankruptcy at the same time was $9 \%{ }^{66}$ The other study examined the turnover rate among the three highest paid executives of fifty-two firms that filed for bankruptcy during the period from 1969 to $1973 .{ }^{67}$ The study showed that $14 \%$ of the managers lost their jobs within one year of filing and $41 \%$ were gone by the end of the second year. ${ }^{68}$ Comparable two-year turnover rates for nonbankrupt companies were probably in the range of 6 to $10 \% .^{69}$ The latter data support the continuing inference that managers of publicly traded companies that file for bankruptcy face substantial risks of losing their jobs.

These data show that the kind of pre-Code/post-Code changes in the control of publicly traded companies that Bradley and Rosenzweig assume simply do not exist. Indeed, the data suggest that managers in the post-Code environment face a substantially higher risk of job loss than did their pre-Code counterparts-70 to $90 \%$ two year turnover rates post-Code versus about 16 to $41 \%$ two year rates pre-Code. Contrary to Bradley and Rosenzweig's assertion, these data are consistent with the hypothesis that shareholders and bondholders do better when management retains control, as they did pre-Code, than they do when management is routinely ousted, as appears to be the case post-Code.

How could Bradley and Rosenzweig have made such a gross error in their analysis of the data? They began their work by citing the pre-Code statute requiring appointment of a trustee in publicly traded cases, and contrasting it with the legal presumption that current management could remain in control under the 1978 Code. $^{70}$ They then jumped to two conclusions: before the Code was adopted, nearly all managers of publicly traded companies were replaced, and after the Code nearly all managers kept their jobs. They assumed that the

65. Jerold B. Wamer, Bankruptcy Costs: Some Evidence, 32 J. FIN. 337, 339 n.5 (1977).

66. Id.

67. James S. Ang \& Jess H. Chua, Corporate Bankruptcy and Job Losses Among Top Level Managers, FIN. MOMT., Winter 1981, at 70.

68. Id. at 72. Managers continued to lose their jobs each year, so that the cumulative effect was that at the end of six years, $80 \%$ had been replaced. This number, however, must be compared with cumulative replacement rates that in general would be in the $18-36 \%$ range.

69. Data on corporate turnovers for the same time period were unavailable, but the data cited supra note 48 support the range listed in the text. See generally Weisbach, supra note 48 , at $438-41$ (reporting a mean annualized tumover rate of 3-5\% for 367 firms listed on Fortune 500 list for 1974-83). For an estimate that most closely covers the time period of the Ang and Chua study see Wamer et al., supra note 48, at 467-69 (reporting mean annual turnover of 0.12 changes per firm for random sample of 269 NYSE- and AMEX-listed firms from 1962-80). As the other data cited supra note 48 suggest, annual turnover rates that do not correct for retirements probably are about twice as large as those that do correct for retirements, making the 3-5\% annual (or 6-10\% two-year) rate a reasonable estimate.

70. See supra text accompanying notes 34-36. 
change in formal rules caused a corresponding change in behavior. But manifestly this change did not occur.

Why would the change in the legal rule fail to produce the behavior Bradley and Rosenzweig assumed it did? To gain some understanding of pre-Code practices, I interviewed George Treister, ${ }^{71}$ a well-respected bankruptcy specialist with extensive experience in business bankruptcies during the 1960's and 1970's, and Judge Robert Ginsberg, ${ }^{72}$ a former law professor and now a bankruptcy judge in the Northern District of lllinois who served with the SEC and was involved in the Chapter X's and Chapter XI's of publicly traded companies during the 1970's.

According to both experts, most publicly traded companies entering bankruptcy initially filed in Chapter $\mathrm{XI} .{ }^{73}$ The company then struggled with the SEC and negotiated with its various creditors to try to devise a consensual plan. If the SEC was persuaded that the public interest would be better served by the flexibility offered by Chapter XI, and if no reason existed to toss out current management, the case remained in Chapter $\mathrm{XI}^{74}$ If the SEC, the debtor, and the major creditors could not agree, the SEC would seek an order from the bankruptcy court to convert the company's filing to a Chapter X, or the creditors might seek to liquidate the company in a straight bankruptcy. The company would often resist, and extensive litigation might follow. ${ }^{75}$

According to those familiar with pre-Code practices, the appointment of a trustee in the large, pre-Code cases did not necessarily mean the replacement of current management. The trustee might have been in nominal control of the business, but the business would still have needed someone with business acumen and familiarity with current operations to run it. According to Mr. Treister, trustees frequently hired old management to run the business after a bankruptcy filing. ${ }^{76}$ After all, the company still needed someone who knew the steel

71. Interview with George Treister, Counsel to Stutman, Treister \& Glatt (May 2, 1992).

72. Telephone Interview with Judge Robert Ginsberg, U.S. Bankruptcy Court, Northern District of Illinois (May 6, 1992).

73. Evidently, Bradley and Rosenzweig assumed this was the case. When I asked Michael Bradley how the pre-Code sample was drawn, he explained that he searched the Wall Street Journal Index for "Chapter XI." When I asked if he searched for "Chapter X," he said, "No." He said he assumed searching "Chapter XI" would give him all the relevant cases, both those that stayed in Chapter XI and those that converted to Chapter VII or Chapter X. Telephone Interview with Michael Bradley, Everett E. Berg Professor of Business Administration, Professor of Finance, Professor of Law, University of Michigan (May 7, 1992) [hereinafter Bradley Interview]; see Bradley \& Rosenzweig, supra note 2, at 1058.

74. Commissioner Longstreth of the SEC reinforced this conclusion when he explained why the SEC was withdrawing from an active role in reorganizations in 1983. SEC Extends Comment Deadline on Role in Chapter II Proceedings, Federal Securities \& Corporate Developments: Securities Regulation Briefs, 21 SEC. REG. \& L. REP. (BNA) 1735 (1989) [hereinafter Securities Regulation Briefs].

75. See generally Richard Epling \& Terence W. Thompson, Securities Disclosure in Bankruptcy, 39 BUs. LAW. 855 (1984).

76. This is not to say that old management was indifferent to the appointment of a trustee. Undoubtedly, many hated the loss of control and the imposition of more stringent reporting requirements that would likely accompany such an appointment. They also feared, like their post-Code counterparts, that they would be replaced. 
business or the shoe business to run the operation. That upwards of $70 \%$ of managers remained in control of their businesses under the pre-Code system was no surprise to those who participated in that system. ${ }^{77}$

\section{Data Biases}

Bradley and Rosenzweig report that their data are based on a study of all publicly traded companies that filed for bankruptcy after the new Code went into effect, which they count as $162,{ }^{78}$ and on all the pre-Code filings of publicly traded companies from 1964 through 1979, which they also count as $162 .{ }^{79}$ There are, however, some unfortunate difficulties with the data base as constructed. First, they miss key groups of cases that could have altered the reported findings. Second, they use nonrepresentative subsets of their data to report stock and bond price changes. And third, they report valuation changes over selected times that may not be representative of overall changes. Because their data base is very small, the problems of data collection and analysis are particularly acute: errors that involve only a few cases can skew the reported results significantly.

Bradley explained that to select their pre-Code cases, they hired a research assistant to search the Wall Street Journal Index with the key phrase "Chapter XI. ${ }^{180}$ This eliminated from the sample all bankruptcies of publicly traded companies that were filed initially in Chapter $X$. When my research assistant sat at the same WSJ Index and searched for "Chapter X" or "Chapter Ten" or "Chapter 10" in the same time period, he immediately located thirty firms that were publicly traded and that filed for bankruptcy between 1963 and 1979, none of which were in the Bradley and Rosenzweig sample. ${ }^{81}$ Although their sample does contain those firms in Chapter X that converted from Chapter XI, it does not contain any firms that filed initially in Chapter $X$. Firms that filed in Chapter $\mathrm{X}$ differed significantly from those that filed initially in Chapter XI. This omission produces a potentially significant bias, and it also raises questions about the overall care with which the data were collected.

77. Both Judge Ginsberg and Mr. Treister noted that the district judge had almost unlimited discretion in choosing the trustee in a Chapter $X$ case. Virtually the only restriction on this discretion was the requirement that the trustee be "disinterested." District judges often used the power to appoint Chapter X trustees to pay political debts. In many Chapter $X$ cases, this led to the appointment of trustees of questionable competence or ethics. Protective Comm'n For Indep. Shareholders of TMT Trailer Ferry, Inc. v. Anderson, 390 U.S. 414 (1968). In virtually every Chapter X case, the identity of the trustee was unpredictable. This uncertainty-and the possibility of an incompetent trustee chosen with no input from the parties involved-was almost certainly a factor management considered when choosing between Chapter X and Chapter XI.

78. Bradley \& Rosenzweig, supra note 2, at 1059.

79. Id. at 1058 \& n.48.

80. The design is detailed supra note 73 .

81. In their research based on publicly traded companies filing bankruptcy between 1939 and 1979 , Professors Clark and Weinstein list 34 Chapter $X$ filings, but it is not possible to determine how many were filed during the second half of this time period. Truman A. Clark and Mark I. Weinstein, The Behavior of the Common Stock of Bankrupt Firms, 38 J. FIN. 489, 498 (1983). 
The number of cases missing from the pre-Code sample is not limited to these thirty. The SEC annual reports list about twenty bankruptcies of public companies in which the SEC intervened each year-a total of more than 300 cases during the pre-Code period Bradley and Rosenzweig cover-but only a tiny fraction of these names appear in their sample. Moreover, the procedure they used for locating cases is also potentially biased because smaller, publicly traded companies that filed for bankruptcy may never have made the pages of the Wall Street Journal. This would again tend to skew the sample. Either Bradley and Rosenzweig's search was defective or they chose selection criteria that produced a biased data base. In either case, they eliminated roughly half of the publicly traded companies that filed pre-Code from an already small data base.

The post-Code Chapter 11 data have similar deficiencies. Smaller publicly traded companies were also eliminated from the sample if their filings were not covered in the WSJ Index, since the Index presents brief summaries of only the top news stories. Although SEC Reports are no longer available to suggest the magnitude of the error, the 1991 Bankruptcy Yearbook gives a clue in its list of the largest Chapter 11 cases. Its list of "Public Companies with Total Assets $>\$ 75$ million Filing Ch. 11 petitions in 1989" (ranked by asset size) has thirtyone entries, of which only four are in the Bradley and Rosenzweig sample. ${ }^{82}$ Morse and Shaw studied fifty publicly traded cases filed between 1980 and 1982 for which they have adequate financial data to compute shareholder losses before and after bankruptcy, ${ }^{83}$ but Bradley and Rosenzweig have only thirty-three publicly traded cases from the same time period in their sample. ${ }^{84}$ LoPucki and Whitford studied forty-three companies with assets greater than $\$ 100$ million at the time of filing that filed and confirmed a plan of reorganization between 1979 and 1988, but fifteen of their cases fail to appear in the Bradley and Rosenzweig list. ${ }^{85}$ Omission of cases from the Morse and Shaw data base are particularly troubling because Morse and Shaw's analysis of fifty cases leads them to conclude that "the 1978 Act had no significant impact on bankruptcy decisions or resolutions for actively traded firms. ${ }^{.86}$ Omission of cases from the LoPucki and Whitford data base is also troubling because the data are based

82. 1991 BANKR. Y.B. \& AlMANAC 33. II).

83. Dale Morse \& Wayne Shaw, Investing in Bankrupt Firms, 43 J. FIN. 1193, 1200 (1988) (Table

84. Bradley \& Rosenzweig, supra note 2, at 1092 (Table A.2). The omission of 17 cases is particularly troubling not only because Shaw and Morse find no post-Code/pre-Code differences, such as those reported by Bradley and Rosenzweig, but also because Morse and Shaw find much higher survival rates in post-Code Chapter 11 cases than those reported by Bradley and Rosenzweig. See Morse \& Shaw, supra note 83, at $1197-99,1206$. These differences suggest that Bradley and Rosenzweig have systematically eliminated more successful cases from their data base.

85. LoPucki \& Whitford, supra note 1 , at 134-35, 139 (Table 1). Those cases include such companies as Air Florida, Amarex, Anglo Energy, Energetics, EPIC, FSC, Marion, MGF, NuCorp, Oxoco, Penn-Dixie, Pizza Time Theater, Tacoma Boatbuilding, Technical Equities, and Wilson Foods.

86. Morse and Shaw, supra note 83, at 1193 . 
on successful Chapter 11 cases whose inclusion would have improved the overall post-Code data. ${ }^{87}$

The data base contains more serious errors. Four of the companies listed by Bradley and Rosenzweig in their bond sample ( $8 \%$ of the total) were not in Chapter $11 .^{88}$ They listed a company that acquired another company that was already in Chapter 11, two companies that were parents of parents of subsidiaries that were in bankruptcy, and a company that was a co-owner of a company that filed for Chapter $11 .^{89}$ Representatives of all four companies were quick to point out in interviews that they were large companies that had never seriously contemplated a bankruptcy filing, notwithstanding Bradley and Rosenzweig's inclusion of these companies in their data base. Since this discovery was only by chance, there is no way to determine whether the error is repeated more times in the sample of fifty-two bond cases, or in the stock sample as well, without replicating all the original research work.

Some of the omissions or inclusions are undoubtedly the result of inadvertent error. Other omissions may have been a deliberate consequence of the selection criteria Bradley and Rosenzweig employed. ${ }^{90}$ But the omission for any reason of a substantial number of other publicly traded cases coupled with the inclusion of companies not in bankruptcy is deeply troubling. With a sample size as small as Bradley and Rosenzweig's, the observed errors alone reduce the reliability of their data to an unacceptable level.

The data problems are exacerbated as Bradley and Rosenzweig progress through their financial analysis. Their claim that shareholders and bondholders lost more in post-Code cases is based on the analysis of financial data from only

87. The question of carelessness plagues these data. For example, the sample includes Gibraltar Finance, which filed on February 2, 1990, but omits both Federated and Allied Stores, which filed on January 15, 1990. (The latter companies also confirmed reorganization plans relatively quickly.)

88. Bradley and Rosenzweig list Alco Standard, K-N Energy, Armco Steel Corp and Clabir Corp as companies whose bond data were used for the calculations reported in their article. I called all four companies, and either the corporate counsel or the communications director of each denied any bankruptcy filing, either in Chapter 11 or in some other chapter.

89. Bradley and Rosenzweig list "Alco Standard" as filing on September 30, 1986. A September 20, 1986, press release shows Alco purchasing Saxon Industries on that day, noting that Saxon had been in Chapter 11. Bradley and Rosenzweig list "K-N Energy" as filing on November 3, 1986. An October 31, 1986, press release from K-N Energy noted that RDI, a subsidiary of Western Oil, which, in turn, was a subsidiary of K-N Energy, would be filing for Chapter 11 soon. This sub-sub-company owned a "de minimis" amount of the total assets of K-N Energy, which were about $\$ 550$ million. Telephone Interview with Dick Buxton, General Counsel of K-N Energy (Sept. 11, 1992). Bradley and Rosenzweig list "Armco STL" Corp. as filing bankruptcy on August 12,1986. The Corporate Communications Officer of Armco explained that Armco owns First Taconite which in turn owned 50\% of Reserve Mining, and that it was Reserve Mining that filed for bankruptcy in August 1986. He pointed out that Reserve Mining's total assets were about $\$ 13.4$ million at the time of the filing, while Armco's assets exceeded $\$ 439$ million. Telephone Interview with Lee Bland, Corporate Communications Officer of Armco Steel Corp. (Sept. 18, 1992). Bradley and Rosenzweig also list "Clabir Corp" as filing on December 17, 1984. Clabir acquired a number of companies during the 1980's. According to press releases at the time, one of the acquisitions was a 39\% stake in Granite Financial Corporation, which filed for bankruptcy in December, 1984.

90. Companies such as Bobbie Brooks, Global Marine, Resorts International, and Southmark are not included in the stock data because, according to Bradley, "they may not have traded during the relevant time period." Bradley Interview, supra note 73. 
a subset of their data base. This subset analysis drops the data base precipitously. The analysis of stock value for post-Code companies is based on only the 116 cases for which data are available through Compustat. ${ }^{91}$ The comparative data for pre-Code cases drop even more precipitously: The pre-Code sample of 157 cases declines to thirty firms for which the relevant stock data are available. ${ }^{92}$ Trading data are based on as few as twenty-three companies. ${ }^{93}$ The bond data also show extraordinary reductions in the data base. The analysis of bond values is based on computations for thirty-seven pre-Code cases and fifty-two post-Code cases $^{94}-24 \%$ and $34 \%$ of the respective samples.

There are two serious problems with the sharp declines in the size of the data base. The first is that a sampling bias may be at work. Some other factor-such as size, success, or trading activity-might cause some companies to continue trading while others suspend trading, so that the resulting analysis is based on a subset that differs from the larger groups of 157 and 162 cases. Bradley and Rosenzweig make no effort to explain why some companies fell out of the sample while others stayed in; nor do they analyze whether the 50\% to $90 \%$ of the public companies eliminated from most computations differ in some systematic way from the companies on which the reported computations were based. The second problem is that when the samples are very small, as the stock and bond samples are in this study, the possibility that a tiny handful of aberrational cases skewed the overall report for the group is very high.

Finally, the Bradley and Rosenzweig data suffer from the possibility that biases are introduced by the time periods covered by the reported data. While Bradley and Rosenzweig announce that they are comparing pre-Code and postCode data, their bond data, for example, compare bond market activity before and after January 1,1978-ten months before the adoption of the Code and nearly two years before its enactment. ${ }^{95}$ Bradley and Rosenzweig defend the date chosen for comparison, saying that this "formulation assumes that the implications of the 1978 Act became apparent to market participants by the beginning of 1978." 96 They assume perfect perception of the implications of a law that had not yet been enacted (or even proposed in its final form) by a

91. Bradley \& Rosenzweig, supra note 2, at 1064 n.60. The reported figure, however, appears to be inconsistent with the 126 firms listed in the post-Code years in Table A.2 of the Appendix, for which they claim these data were available. $I d$. at 1092.

92. Id. at 1064 n.60.

93. id. at 1074 (Table 10).

94. Table 8 reports no $n$ for the number of companies used for the analysis, but it lists the number of bonds in each cell. The numbers go as high as 105 . Id. at 1072. This does not mean, however, that these are the bond issues from 105 companies. Instead, it means that the data are based on data of 105 bond issues, with multiple issues from several companies. In the bond data list provided to the Yale Law Journal, Bradley and Rosenzweig indicate that their sample is based on 42 pre- and 64 post-Code companies, with a total of 77 pre-and 117 post-Code issues. The data reported in Table 8 , then, are from shifting (and unidentified) subsets of these companies and their bonds.

95. The Code was adopted on November 6, 1978, and became effective for cases filed after October 1, 1979. Pub. L. No. 95-598, Tit. I, § 402, 92 Stat. 2682 (1978).

96. Bradley \& Rosenzweig, supra note 2 , at 1070. 
market that had had no experience with companies filing for bankruptcy under it. Without this presumption of extraordinary prescience, these data are meaningless.

This problem is made more severe by the manner in which Bradley and Rosenzweig treat relevant empirical findings. Two earlier studies demonstrated that the market anticipates corporate bankruptcies four to six years prior to bankruptcy, ${ }^{97}$ but Bradley and Rosenzweig use bond data for only a year before filing, without discussing the previous research in the field or explaining the dates they choose..$^{98}$ At the same time, they dismiss the contrary findings of another study that shows no pre- and post-Code differences in stock valuations, and they justify this dismissal by saying merely that the other study covered cases over a shorter time period. ${ }^{99}$ It is impossible to determine whether the reported rates of return and default premiums calculated by Bradley and Rosenzweig represent important differences among the bonds of bankrupt companies pre- and post-Code, or whether the differences are merely statistical anomalies that show up in the short time periods covered by the bond data but which would disappear in a longer time frame, such as that used for the stock data. ${ }^{100}$

97. RANDOLPH WESTERFIELD, ASSESSMENT OF BANKRUPTCY RISK (1971); J. Aharony et al., An Analysis of Risk and Return Characteristics of Corporate Bankruptcy Using Capital Market Data, 35 J. FIN. 1001 (1980).

98. Bradley \& Rosenzweig, supra note 2, at 1072 (Table 8). This omission is particularly startling since Bradley and Rosenzweig use the Clark and Weinstein findings, supra note 81 , to bolster their own regarding stock losses, without noting that the latter study is based on different time periods. id. at 1069 n.65.

99. Id. The study they dismiss is Dale Morse \& Wayne Shaw, Investing in Bankrupt Firms, $43 \mathrm{~J}$. FN. 1193 (1988) (finding no difference in wealth losses among shareholders of publicly traded firms 1973-79 an? 1980-82). Their casual dismissal is troubling because the Morse-Shaw study covers 162 firms-over half of the total number of firms studied by Bradley and Rosenzweig. Moreover, 50 of the cases studied by Morse and Shaw are post-Code cases-nearly a third of the Bradley and Rosenzweig post-Code sample. If no discernible differences in shareholder value could be detected among the pre- and post-Code group using the same indices Bradley and Rosenzweig use, it might have been useful for Bradley and Rosenzweig to look more closely at Morse and Shaw's data to try to explain why that should be so.

100. Similarly, the time series analysis in Table 2 presumes that the only relevant date is the date of adoption of the Code. Bradley \& Rosenzweig, supra note 2, at 1059. This approach conceals any differences that occur at times other than the Code adoption. If, for example, rates of return were comparatively low in the 1960's, and consistent from the 1970's through the 1990's, the data reported in Table 2 would be entirely accurate as reported, and yet it would not be appropriate to presume that the adoption of the 1978 Code caused the differences. Without more detailed reporting, the time series are virtually worthless. The same problem presents itself in nearly all of Bradley and Rosenzweig's comparison tables.

There is a related problem in Tables $3 A$ and $3 B$. Bradley and Rosenzweig perform a time-series analysis of the frequency of bankruptcy filings. They assume it takes one year for bankruptcy filings to reflect a market decline. Bradley \& Rosenzweig, supra note 2, at 1061. But if, for example, larger firms filing postCode can withstand their difficulties longer, two or three years might intervene between the time the problem was reflected in a market decline and any increase in bankruptcy filings. Westerfield's and Aharony's studies both show a four to six year period before a bankruptcy filing when the market reflects the perceived risk of a coming bankruptcy. See supra note 97. If a different time series were chosen for the Bradley and Rosenzweig analysis, the reported data might change. Again, it is impossible to make this determination from the data they report. 


\section{E. Multiple Causation}

Even if the Bradley and Rosenzweig data were reliable and were not contradicted by other data, their findings would not confirm their hypothesis of management misbehavior unless they had eliminated alternative explanations for the results they present. If other events of the period under consideration could account both for a rise in bankruptcy filings by publicly traded companies and for increased losses to their shareholders and bondholders, the idea that there is a causal link between the data they report and the hypothesis they wish to test remains unsubstantiated. There are two sorts of alternative explanations Bradley and Rosenzweig should have considered. First, a number of other important factors outside the bankruptcy system could plausibly have produced the reported results. Second, managers of troubled companies made different filing decisions in the 1980's than they had in earlier decades for reasons other than that suggested by Bradley and Rosenzweig.

The economic environment for companies operating during the 1980's was substantially different from the environment of the preceding two decades. During the 1980's, inflation rates reached record levels and then subsided, ${ }^{101}$ causing wild gyrations in the costs of corporate debt. Closely related to the extraordinary changes in inflation rates were the changes in interest rates, which also rose sharply, then declined. ${ }^{102}$ Federal debt tripled during the 1980 's, ${ }^{103}$ increasing the competition for borrowing dollars and affecting both inflation and interest rates. In addition, capital markets changed dramatically. Privatelyheld debt expanded rapidly, ${ }^{104}$ and a secondary mortgage market emerged and grew, ${ }^{105}$ both of which signal a departure from the near-monopoly banks once had over financial transactions of this sort. Foreign investments also rose, ${ }^{106}$ changing the power of certain investment houses and the profitability of established investment strategies.

The leveraged buyout phenomenon provides perhaps the best example of the changing business environment of the 1980's. Leveraged buyouts (LBO's)

101. U.S. DEPT. OF COMMERCE, STATISTICAL ABSTRACT OF THE UNTED STATES 1991, at 473, 475 (11th ed. 1991) [hereinafter STATISTICAL ABSTRACT].

102. The effective rate on federal funds in 1980 was $13.36 \%$, rising to $16.38 \%$ by 1981 . By 1986 that rate had dropped to $6.8 \%$, and by 1990 it was at $8.10 \%$. Id. at 512 . Perhaps more critically, investor perceptions changed. "Around 1980 capital suppliers changed from believing that inflation rates would remain low to believing that those rates would be relatively high." ANTHONY DOWNS, THE REVOLUTION IN REAL ESTATE FINANCE 1 (1988).

103. STATISTICAL ABSTRACT, supra note 101, at 279.

104. Ownership of public debt securities by private investors rose from $\$ 616.4$ billion in 1980 to $\$ 2,015.8$ billion in 1989. Id. at 499 . The share of debt held by commercial banks was cut in half during the same decade. Id. Mortgage debt more than doubled in the same time period. Id. at 507.

105. DowNs, supra note 102, at 24 (noting secondary markets now account for more than half of funds flowing into residential markets in recent years).

106. BELA BALASSA \& MARCUS NOLAND, JAPAN IN THE WORLD ECONOMY 119, (1988) (Table 5.1) (Japanese investment in U.S. rose from $\$ 905$ million in 1975 to $\$ 15,357$ million in 1987). 
grew fifteen-fold, ${ }^{107}$ as mergers and acquisitions reached unprecedented levels. ${ }^{108}$ To finance these acquisitions-or to avoid becoming a target themselves - companies loaded up on debt. In the most extreme cases, they issued highly leveraged debt instruments known as junk bonds. The resulting debt-laden companies had a much lower tolerance for fluctuations in the business environment that depressed earnings and impaired their ability to meet debt obligations. This put these companies at risk for default and, eventually, bankruptcy. Not surprisingly, the Bradley and Rosenzweig post-Code bond data are filled with companies issuing junk bonds. More than $46 \%$ of the issues in their sample were from companies issuing junk bonds, ${ }^{109}$ which suggests that the post-Code reported data were sharply influenced by the debt-loading phenomena. The stock data reflect the consequences of too much debt as well. As shareholders recognized the weakening of their positions following an LBO, they demanded a compensating risk premium as well. ${ }^{110}$

The Bradley and Rosenzweig data are consistent with a story about companies that take on too much debt. Given the changes in corporate financing and the romance with LBO's, it would be surprising if there were not a rise in filing among publicly traded companies and a change in the stock and bond prices of companies in serious financial trouble. ${ }^{111}$ The relatively slow growth

107. See, e.g., Richard M. Cieri et al., An Introduction to Legal and Practical Considerations in the Restructuring of Troubled Leveraged Buyouts, 45 Bus. LAW. 333 (1989).

108. See, e.g., MARGARET H. PICKERING, A REVIEW OF CORPORATE RESTRUCTURING ACTIVITY, 1980-90, at 11 (Table A.I) (Board of Governors of the Fed. Reserve Sys. Staff Studies Series No. 161, 1991); Ralph S. Saul, Hostile Takeovers: What Should Be Done?, HARV. Bus. REV., Sept-Oct. 1985, at 18. The total volume of announced mergers and activities in the decade before adoption of the Bankruptcy Code was $\$ 206.3$ billion, while the total volume in the decade following the adoption of the Code was $\$ 1,360.6$ billion.

109. Junk bonds figure even more prominently in the data because companies issuing junk bonds tend to have multiple entries in the Bradley and Rosenzweig data. Of the 52 companies included in the bond analysis, 21 (40\%) were junk bond issuers. But of the 95 issues on which the computations were based, 46\% were from companies issuing junk. It is impossible to tell whether or not an issue is a junk bond from the data Bradley and Rosenzweig report. It is possible to tell, however, that the companies they studied issued junk bonds and that junk bonds figured prominently in these data.

110. Comments from the junk bond king, Michael Milken, suggest a change in perspective in the bond market between the 1970's and the 1980's:

[I]nvestors had several years' experience that had taught them corporate bonds were a sound investment even if they weren't top-rated credits. In 1970 and 1974 hundreds of companies that everyone on Wall Street believed would go bankrupt didn't, and people who bought their bonds did very well.

James W. Michaels and Phyllis Berman, My Story-Michael Milken, FoRBEs, Mar. 16, 1992 at 78, 83. In the late 1980's, however, the junk bond market was in a panic. Id. Not surprisingly, Milkin defends the junk instruments but notes that a very different stock market, with discounts to replacement value and changing investor perceptions, completely altered the bond market during the late 1980's. One need not accept Milken's view of the world to believe that the bond markets in the 1980's changed substantially from the market of the 1970 's. These changes may not reflect favorably on managers, but the alteration in their behavior presumably had little to do with incentives created in 1978 by changes in Chapter 11.

111. One market observer explains:

Leveraged buy-outs have become so huge that investors now realise that almost every company's bonds are under the threat of instant conversion into junk. . . . [When RJR Nabisco announced it was going to increase its debt to do an $\mathrm{LBO}$ ] prices of its long-term bonds fell by as much as $20 \%$. The result was a paper loss of around $\$ 800$ million on RJR Nabisco's $\$ 5.4$ billion of outstanding debt securities. 
of bankruptcy filings among publicly traded companies during the 1980's may suggest a reluctance to enter bankruptcy if it could be avoided. Thus, while the reports from the 1980's may suggest management misbehavior, blaming the LBO phenomenon on changes in the bankruptcy laws requires an extraordinary causal leap.

The examples of changes in the economic environment from the 1970's to the 1980's go well beyond the LBO example. Deregulation was the watchword of the 1980's, as government agencies began to reduce constraints on competition in certain industries, thus bringing about the failure of competitors who could not adapt quickly. ${ }^{12}$ Also during the 1980 's, mass tort liabilities began to surface. ${ }^{113}$ Underfunded pension plans created staggering liabilities for some companies. ${ }^{114}$ Rising environmental liability and increasing regulatory enforcement also began to have an economic impact. ${ }^{115}$

Some industries took especially hard hits during the 1980's, and their problems are reflected in the Bradley and Rosenzweig data. Among the 162 companies they list as filing in the 1980's, twenty-one are in the oil industry. The newly deregulated transportation industry accounts for nineteen more. Bankruptcies in the steel and metals industry add another fourteen, while the real estate industry contributes sixteen. Financial services account for thirteen of the bankruptcies. Declines in retail sales are reflected in the bankruptcies of eight publicly traded retailers and thirty-one suppliers and manufacturers of consumer goods. These six industries-oil, transportation, steel, housing, financial services, and retail sales-account for 122 of the 162 filings in the Bradley and Rosenzweig post-Code sample, making up $75 \%$ of the filings of all publicly

A Big Event for American Bonds, EcoNOMIST, Oct. 29, 1988, at 81. The analyst went on to explain how the fallout spread to the rest of the industrial sector of the market, forcing up yields on all bonds. Bradley and Rosenzweig attempt to blame the decline in post-Code bond prices on the threat of bankruptcy and the bankruptcy premium, but the post-Code decline in bond prices occurred without these two factors present.

112. Craig C. Carter, Death to the ICC, FORTUNE, Feb. 3, 1986, at 101; Myron Magnet, The Service 500: It's Shape Up or Shake Out in a Shook-Up World, ForTUNE, June 10, 1985, at 166.

113. Susan Narod, Lawyer Views U.S. Litigation Explosion, NATIONAL UNDERWRITER CO., PROPERTY \& CASUALTY/EMPLOYEE BENEFTTS EDITION, Apr. 11, 1988, available in LEXIS, Nexis Library, Nuprop file (showing 12 million civil suits filed in 1985 in U.S. and 402 awards of $\$ 1$ million or more-15 times as many as in 1975).

114. Growth in Pension Holdings, Coverage Detailed In New Book Published by PWBA, 17 Pens. Rep. (BNA) No. 3, at 144 (Jan. 15, 1990) (1981-85 exceeded all other periods over past 40 years in rate of growth of defined contribution plans); PBGC's 1991 Deficit to Reach Over \$2 Billion, Lockhart Reports, BNA PENSIONS \& BENEFTSS DAILY, Dec. 12, 1991, available in LEXIS, Nexis Library, BNApen file (pension underfunding increased $50 \%$ between 1989 and 1990).

115. See, e.g., Capital Hill Issues, U.S. NEWS \& WORLD REP., Feb. 25, 1985, at 48 (\$5-10 billion needed over next four years for environmental clean up); Air Standards Could Cost TVA \$113 million, UPI, Jan. 26, 1985, available in LEXIS, Nexis Library, Upstat file; Remarks by President Bush to the Ohio Association of Broadcasters, Federal Information Systems, Apr. 30, 1992, available in LEXIS, Nexis Library, Fednew file (cost of environmental compliances is $\$ 1.6$ billion for city of Columbus); Stockholders Hear Review of Outlook, Operations: Kerr-McGee Building on a Solid Foundation, PR Newswire Association, May 5, 1992, available in LEXIS, Nexis Library, PRnews file (annualized cost for pollution control has risen in constant dollars from $\$ 30$ billion in 1972 to $\$ 115$ billion in 1990). 
traded companies. ${ }^{116}$ Considering the numerous problems companies of these types confronted during this period, it seems unlikely that the critical factor in their failure was that management faced a kinder, gentler Bankruptcy Code.

The problem of multiple causation appears in yet another form. The Bradley and Rosenzweig data are consistent with a hypothesis directly counter to their own. If the number and magnitude of business failures remained constant while the attitude of debtors about the usefulness of bankruptcy shifted, we would predict data such as those Bradley and Rosenzweig report. These data may reflect changes in the bankruptcy decisions made by debtors themselves, rather than indicating more frequent and larger failures. During the 1980's, debtors might have decided to file earlier in the decline of a business or to file bankruptcy rather than simply to close the company down or hand it over to the toughest creditor. If they made such decisions, the reported declines in the value of Chapter 11 companies during the 1980's may mean only that more failing companies are now liquidated through bankruptcy than privately and that debtor self-selection alters the mix of businesses in bankruptcy.

A great deal of anecdotal evidence suggests that some debtors who would simply have liquidated or sold their businesses to other companies in the preCode environment now see bankruptcy as a viable means of financial restructuring. The large, publicly traded companies that filed for bankruptcy in the 1980's differed substantially from those that filed in earlier periods. Before the 1980 's, for example, nearly all experts believed that a company that sold products directly to the public could not go into bankruptcy and survive. People would be so repelled by the bankruptcy filing, it was thought, that the company might as well liquidate without filing. ${ }^{117}$ The 1980 's saw a significant change in this perception. Among those in the bankruptcy sample examined by Bradley and Rosenzweig were Allis-Chalmers Machinery, Braniff Airlines, Coleco Toys, Continental Airlines, Eastern Airlines, First Pennsylvania Bank Corporation, First Republicbank Corporation, Flanigan's Restaurants, Heck's Department Stores, Interstate Motor Hotels, Itel Financial Services, Lionel Toys, Lomas Financial Corporation, MacGregor Sporting Goods, Mays Department Stores, Penn Dixie Groceries, Rath Meatpacking, Revere Copper, A.H. Robins Pharmaceuticals, Sambo's Restaurants, Shearson Lehman Brokerage, Sunbeam,

116. The bond data show similar problems. The pre-Code bond cases include bonds issued by nine real estate investment trusts (REIT's) that filed for bankruptcy in that period-nearly one-quarter of the entire pre-Code bond sample of 33 cases. By comparison, the post-Code bond cases have no REIT's. But the postCode cases illustrate their own industry problems: they are laden with bonds issued in the oil and gas industry (9), the construction industry (4), and the transportation industry (10). These three industries account for nearly half of the entire post-Code bond sample.

117. A few large, consumer-oriented companies filed under the Act, such as W.T. Grant and Arlans Department Store, but they were rare exceptions-and they eventually folded. See, e.g., Company Reports, N.Y. TIMES, Jan. 22, 1975, at 64 (Arlan's Department Stores to liquidate); Grant Adjudged Bankruptcy, FACTS ON FILE WORLD NEWS DIG., Dec. 31, 1976, at 984. 
Texaco Oil, and Wickes Lumber. ${ }^{118}$ While some of these huge, consumeroriented companies failed, others succeeded, thereby changing significantly the perceived viability of Chapter $11 .{ }^{119}$

Another indication that different businesses may now be using bankruptcy is the increased willingness of very large companies to seek bankruptcy protection. ${ }^{120}$ Indeed, the phenomenon of large companies filing for bankruptcy came on the scene with such speed and force in the 1980's that it acquired its own name: the megabankruptcy. ${ }^{121}$ Companies with more than a billion dollars in assets are thus no longer rarities in Chapter $11 .{ }^{122}$ The comparison with just a dozen years earlier is telling: A list of the forty largest bankruptcy filings (in constant dollars) shows that thirty-eight of the forty biggest cases ever filed are from the post-Code era. ${ }^{123}$ The total number of bankruptcies of publicly traded companies has remained stable from 1970 through 1990 while the number of megabankruptcies has risen, which supports the theory that a different pool of debtors filed for bankruptcy during the 1980 's than filed pre-Code. ${ }^{124}$

If the data established that greater losses were imposed on bondholders and shareholders in the months immediately surrounding the bankruptcy filing, it does not necessarily follow that total losses are greater because of the new laws, as Bradley and Rosenzweig assert. The correct inference may be instead that more business failures are being handled in bankruptcy than ever before. And as different kinds of public companies choose to enter Chapter 11, it would not be surprising if the performance of these companies differed from that of

118. Once again, the difference between the pre-Code sample and the post-Code sample is noticeable. There are 20 companies in the post-Code sample that are readily identifiable as businesses with large sales to the public, while in the pre-Code sample, there are only four such businesses. Michael Bradley \& Michael Rosenzweig, Listing of Bonds in Pre-1980 Bond Sample (1992) (on file with author).

119. One commentator describes the 1982 filing of Johns-Manville as a "dramatic watershed." Diana B. Henriques, The Vulture Game, N.Y. TMES MAG., July 19, 1992, at 18, 22 (quoting Martin Nussbaum, Wall Street securities lawyer). Mr. Nussbaum goes on to discuss the Texaco bankruptcy the following year, a bankruptcy that "would have been unthinkable 20 years ago." Id.

120. In a review of the data on business failure and bankruptcy, Professor Eisenberg concluded that "there has been a striking increase in the percentage of failing business firms that resort to Chapter 11." Theodore Eisenberg, Baseline Problems in Assessing Chapter II, U. TORONTO FAC. L. REV. (forthcoming Summer 1993) (manuscript at 24, on file with author).

121. A megabankruptcy is a bankruptcy of any company with assets in excess of $\$ 100$ million. Some observers believe this threshold is too low and thus that the category of megabankruptcies includes too many of today's filings. See generally ELZZABETH GIBSON, A GUDE TO THE JUDICLAL MANAGEMENT OF BANKRUPTCY-MEGACASES (1992).

122. 1992 BANKR. Y.B. \& ALMANAC 53.

123. Id. The only pre-Code cases to make the list are Penn Central Railroad and W.T. Grant. Bradley \& Rosenzweig, supra note 118.

124. The megabankruptcy phenomenon may reflect other changes, such as changes in the business environment that have made larger companies more vulnerable than before. Throughout the 1960's and 1970's, larger companies may simply have been more resistant to lawsuits, deregulation, shifts in retailing, and other factors which might have caused some of the biggest companies to file in the 1980's. Or it may be that other business activities, such as mergers, acquisitions, and LBO's, which were rare in the 1960's and 1970's, explain the rise in big-company bankruptcies in the 1980's. It is also possible that more companies have simply grown internally or through acquisitions. The size of companies in bankruptcy would then also be expected to increase, although the number of billion-dollar-plus companies in bankruptcy outstrips any general growth trends. 1992 BANKR. Y.B. \& ALMANAC 53. 
companies filing ten to thirty years earlier. The data do not compare the preand post-Code total returns from all failing businesses, as Bradley and Rosenzweig imply. Instead, they only show that different debtors now deal with their failures through bankruptcy than did in the past.

It is also possible that businesses in distress are now filing at a different stage of financial collapse. When Congress passed the new Bankruptcy Code, one of its explicit goals was to encourage ailing companies to seek bankruptcy reorganization earlier in the process, when there remains a significant chance of saving the business. ${ }^{125}$ If the Code is achieving its intended goal, and if companies that need reorganization are filing for bankruptcy at an earlier stage in their collapse post-Code than they did pre-Code, we would expect to see differences in the pre- and post-Code financial data.

The data collected by Bradley and Rosenzweig suggest that Chapter 11 is working better than it did a decade ago. The data show that the relative strength of the post-Code companies filing for bankruptcy is greater at the date of filing ${ }^{126}$ and that the relative short-term survival rate of the post-Code companies has risen somewhat ${ }^{127}$ Companies that delayed filing until the business was at death's door, as so many did in the 1960's and 1970's, may have been near their lowest valuations for a substantial period of time before they filed. Other companies may have simply collapsed without ever filing for bankruptcy. By contrast, companies that filed earlier in the process may have had more value to lose. And by filing earlier, more companies that might have failed without filing in the pre-Code era may now show up as "bankruptcy failures" in the post-Code era. ${ }^{128}$ The data offered support the working hypothesis that managers are taking failing firms into bankruptcy at an earlier stage and, perhaps as a result, are saving more of them.

The presence of a plausible alternative hypothesis consistent with Bradley and Rosenzweig's reported results leaves open two conflicting explanations for their findings. This is like discovering that the results of a medical test are consistent with two diagnoses: the patient is ill and the patient is healthy. Bradley and Rosenzweig conclude the patient is so ill that the entire Chapter 11 system should be scrapped. I argue that it is equally plausible that the patient is healthy,

125. See, e.g., H.R. Rep. No. 595, 95 th Cong., 2d Sess. 232-34 (1977), reprinted in 1978 U.S.C.C.A.N. 5963, 6191-94 (expressing congressional concem over delays in filing that decrease the chances for business survival).

126. Bradley \& Rosenzweig, supra note 2, at 1063-66. The conclusion of greater strength is based on data showing stronger pre-filing eamings and fewer delistings prior to bankruptcy among the publicly traded companies that file for bankruptcy post-Code.

127. Id. at 1075 (Table 11). The data show a two-year survival rate of $83.3 \%$ post-Code (compared with $74.5 \%$ pre-Code) and a four-year survival rate of $61.7 \%$ post-Code (compared with $59.2 \%$ pre-Code).

128. The time periods covered by the Bradley and Rosenzweig data exacerbate this problem. They report that the post-Code firms show a greater decline in value as measured by stock prices during the two years preceding bankruptcy and by bond prices in the period from one year before filing to six months after filing. Id. at 1068 (Table 6), 1072 (Table 8). If companies filed earlier in their demise after the Code, the Bradley and Rosenzweig data would miss these changes. 
and that there is some evidence to suggest that the system is working as it should - encouraging more troubled businesses to deal with their problems earlier and consequently saving more of those businesses. At a minimum, it would seem prudent to run more tests before we run the risk of burying the patient alive.

Bradley and Rosenzweig try to cope with the problem of multiple causation by arguing that there has not been an overall weakening in the economy or an increase in the number of financially troubled firms. ${ }^{129}$ They rely on a single test - the overall rate of return on stocks-to reach this conclusion, ${ }^{130}$ and develop a time-series analysis of the frequency of bankruptcy filings to show that bankruptcy filing rates do not correlate with overall market returns in a specified period. ${ }^{131}$ They argue that this "result is consistent with our assertion that a bankruptcy filing is a more endogenous event in the post-Act Chapter 11 environment." 132

By using overall market rates of return in their time series regression, however, Bradley and Rosenzweig learn little about the increased risks facing certain companies. Aggregate data hide variations in the fortunes of individual companies. Increased volatility will produce simultaneous increases in business successes and business failures. The successes may outweigh the failures, producing an overall positive effect, but the aggregated data will conceal the jump in the number of failures. This problem was particularly acute during the 1980's. Frenzied takeover activity and waves of deregulation produced extraordinary gains for those who anticipated the changes correctly and adjusted quickly. But those same conditions left a wave of business failures, many of which were swept along into the bankruptcy court.

The numbers Bradley and Rosenzweig cite about overall stock market rises during the 1980's encompass far too few variables to eliminate the problem of multiple causation. When the valuation data they present support other reasonable

129. Id. at 1076.

130. In order to explore the same question, other researchers use a number of different tests, including, for example, tests of correlations between bankruptcy filings and growth in the GNP, and between bankruptcy filings and changes in the GNP. See, e.g., 1992 BANKR. Y.B. \& ALMANAC 339. It is troubling that Bradley and Rosenzweig do not even use all of their own data to combat the inference of multiple causation. They report no similar time series analysis for the bond data, raising the uncomfortable question of whether such a series would have revealed contrary results.

131. Bradley \& Rosenzweig, supra note 2, at 1061-62 (Tables 3A \& 3B). Such time lags are highly problematic. They begin with the presumption that the length of time from an economic reversal to a bankruptcy filing for an affected company is a known phenomenon. When Bradley and Rosenzweig observe a time-lag correlation for pre-Code filings and no correlation for post-Code filings, they may only be noting a change in the lag period. If companies could withstand shocks longer or if they filed earlier in their economic demise, for example, the time lag would necessarily change. This inference would be consistent with Bradley and Rosenzweig's other findings that after the new Code was passed companies filed when they were in better overall financial condition. Id. at 1063-64.

132. Id. at 1062 . Other researchers draw somewhat different conclusions. During pre-Code years only the big recession of 1974-75 yielded substantial increases in bankruptcy filings, and over the 1960 's, a decade of constant growth, bankruptcy filings rose. In the post-Code period, business filings were up during 1982 and 1991 - both years of recession. "Business filings do move with the economy, at least in part." 1992 BANKR. Y.B. \& ALMANAC 339. 
interpretations, the critical causal link between their data and their hypothesis disappears.

\section{LOSING VALUE OR REDISTRIBUTING VALUE?}

Bradley and Rosenzweig's work rests on the premise that bankruptcy has a single goal: preservation of value for public shareholders and bondholders. ${ }^{133}$ If this assumption had not been among their unstated premises, they could not have recommended the repeal of Chapter 11 on the basis of their results.

Bankruptcy functions to preserve value in faltering businesses and to enhance the return to all those who have an interest in the business, but it also serves to redistribute value. Even if redistributional goals are inadequate to justify an extremely inefficient system, I would argue that they are sufficiently important to justify slight inefficiencies. Moreover, the data presented by Bradley and Rosenzweig do not illustrate system inefficiencies. Even if the data demonstrated that bondholders and shareholders lost greater value in post-Code reorganizations, it does not show that the value simply disappeared. The value that no longer goes to shareholders or bondholders after the adoption of the new Code may now be distributed to other parties in the bankruptcy process, such as secured creditors, trade creditors, and employees. In this Section, I discuss the distributive impact of bankruptcy, and I examine evidence that what Bradley and Rosenzweig characterize as "loss" may simply be redistribution to other parties. Finally, I consider briefly the redistributive consequences of Bradley and Rosenzweig's proposal to repeal Chapter 11.

\section{A. Redistributional Goals of Bankruptcy}

Bankruptcy law is deliberately designed to distribute assets-and losses-when a business cannot meet its outstanding obligations. ${ }^{134}$ When Congress passed the Bankruptcy Code, it made a great number of distributional decisions. The Code devotes considerable attention, for example, to the relative rights of secured creditors versus all other interested parties. It also treats the competing interests of employees, taxing authorities, U.S. fishermen, farmers, landlords, business partners, parties to executory contracts, beneficiaries of statutory liens, ordinary course creditors, and creditors with setoff rights-to name just a few. ${ }^{135}$ Virtually every substantive amendment to the Bankruptcy Code since its passage in 1978 has specifically addressed redistributional

133. Bradley \& Rosenzweig, supra note 2, at 1043-44.

134. See, e.g., Elizabeth Warren, Why Have a Federal Bankruptcy System?, 77 CORNELL L. REv. 2401 (1992); Elizabeth Warren, Bankruptcy Policy, 54 U. CHI. L. REv. 775, 785-86 (1987) ("Distribution among creditors is not incidental to other concerns; it is the center of the bankruptcy scheme."). See also WARREN \& WESTBROOK, DEBTORS AND CREDITORS, supra note 62, at 407-09, 427-30.

135. Warren, Bankruptcy Policy, supra note 134 , at 786 \& n.20. 
concerns. This means that the assets of the bankrupt debtor have been redistributed to favor some creditors-and necessarily to disfavor others.

The Code is thus designed not only to enhance the value of the failing business, but also to distribute that value among interested parties in specified ways. Moreover, just as enhancement of value is only one of the goals of bankruptcy, preservation of the business as a going concern is only one of the ways the Code enhances the value of the estate. ${ }^{136}$ Like any system that serves multiple purposes, goals sometimes conflict, and different aspects of the law may favor one goal over another under certain circumstances.

Even if Bradley and Rosenzweig had been able to produce data incorporating the full range of redistribution, and thus overall preservation of value could have been estimated, the inquiry would be incomplete. If the value enhancement goal and the redistributive goals conflict-as would be the case if it turned out that bankruptcy reduced total value but allocated a larger portion of the remaining value to certain preferred creditors who would not receive such protection without bankruptcy-it would remain an open question whether Chapter 11 should be dismantled. The question would present itself in cost-benefit terms: policymakers would have to decide whether the costs of the overall losses are so large that they outweigh the benefits of redistribution. If they are, the laws would have to be restructured, but if they are not, policymakers would conclude that the system should remain intact. Of course, the policymakers would also have to consider whether it is possible to reduce the overall costs of bankruptcy while preserving its redistributive effects. In any case, that inquiry stretches far beyond the data presented here, because these data, even if taken at face value, show only that a group of public debt and equity holders have lost value; they do not rule out the possibility that other groups have corresponding gains.

\section{Distribution Away From Public Bondholders and Shareholders}

Tracing redistributive consequences is extraordinarily difficult, but there is substantial evidence that Congress intended public bondholders and shareholders to bear a greater share of the losses of failing companies. In the hearings leading up to the 1978 Code, Congress singled out a number of beneficiaries of its distributional decisions, making repeated references to protecting jobs and saving troubled businesses. ${ }^{137}$ Concern for bondholders and stockholders is not in evidence either in the legislative history or in the ultimate Code enactment.

136. In fact, bankruptcy laws are designed to preserve value in a number of different ways, not just to avoid liquidation losses, as Bradley and Rosenzweig assert. By providing a mechanism for creditors to work together, for example, bankruptcy laws are designed to reduce duplicate collection efforts and thereby to reduce costs. Similarly, by providing a much higher degree of supervision over the debtor than is generally available in state law, bankruptcy laws reduce collection costs. See ELIZABETH WARREN, BUSINESS BANKRUPTCY (forthcoming Dec. 1992).

137. See, e.g., 124 CONG. REC. 32,392 (1978) (statement of Rep. Edwards); 124 CONG. REC. 33,990 (1978) (statement of Sen. DeConcini). 
More critically, Congress actively pursued redistributional strategies vis-à-vis public bondholders and shareholders of bankrupt companies through changes in the role of the Securities and Exchange Commission. Under pre-Code law, the SEC was an active participant in reorganization proceedings for publicly traded companies, a role it was assigned in 1938 concurrent with the adoption of Chapter X of the Chandler Act. The Commission's participation had been recommended by the SEC Protective Committee Study of insolvency cases in the 1920's and 1930's, which documented significant fraud against public bondholders and stockholders in bankruptcy cases and other forms of insolvency reorganization. ${ }^{138}$ By the time the laws were reevaluated in the 1970's, the practical role of the SEC had changed. A "large and vigorous plaintiffs' bar, anxious to represent public security holders in any case where they are being unfairly treated" had arisen to monitor public companies. ${ }^{139}$ The SEC came to be seen as an intransigent force, arguing for mechanical application of economic doctrines from the 1930's and 1940's, which were unhelpful in resolving the economic problems of the 1970 's. ${ }^{140}$ The participation of the SEC in reorganization cases received increasing criticism for driving up the costs of bankruptcies. ${ }^{141}$ In response, the new Code sharply reduced the influence of the SEC. Commissioner Longstreth explained why a reduced role for the SEC was appropriate:

In Chapter 11, investors are but one class among many deserving protection. Assuming no clear legal right demanding vindication on behalf of investors and the adequacy of their representation through committees and counsel, it is surely not the Commission's function to throw its weight behind the interests of investors in the context of Chapter 11, because to the extent the Commission is successful, investor gains result in corresponding losses to other legitimate claimants, such as trade creditors, customers, employees and the like. ${ }^{142}$

138. HOUSE COMM. ON THE JUDICIARY, REPORT TO ACCOMPANY H.R. 8200, H.R. REP. NO. 95-595, 95th Cong., lst Sess. (1977).

139. Id.

140. The SEC explained its own participation: "[The Commission] pays special attention to the interests of public security holders who may not otherwise be represented effectively." SECURTIIES AND EXCHANGE COMMISSION, 36TH ANNUAL REPORT, Part VII, PARTICIPATION IN CORPORATE REORGANIZATIONS 174 (1970); Aaron Levy, The Role of the Securities and Exchange Commission and the Judicial Functions Under the Bankruptcy Reform Act of 1978, 54 AM. BANKR. L.J. 29, 30 (1980) (quoting testimony in support of SEC participation to ensure a trustee who "can be expected to look out for the debt and equity holders").

141. "By the mid-seventies a pattern was developing in which the company would file in Chapter XI, the SEC would move for conversion to Chapter X, and then the company and the SEC would negotiate about the treatment of public debtholders and shareholders, with the Commission in effect offering to permit the case to remain in Chapter XI if the public was given good treatment. Institutional lenders, like banks and insurance companies, increasingly felt that this process was working to their disadvantage." WARREN \& WESTBROOK, DEBTORS AND CREDITORS, supra note 62, at 397.

142. Securities and Exchange Commission's Role in Bankruptcy Reorganization Proceedings, Fed. Sec. L. Rep. (CCH) $86,445,86,447$ (1983). 
Citing "serious questions of fairness,"143 the SEC further curtailed its own participation in the bankruptcies of publicly traded companies in $1983 .{ }^{194}$

If Bradley and Rosenzweig's data show that bondholders and shareholders generally fared better under the pre-Code system than they have since the enactment of the Code, a logical conclusion is that different distributional forces are at work. The data suggest that reducing SEC participation has had its anticipated effect, and that shareholders and bondholders in the publicly traded Chapter 11 cases are not doing as well because they are required to fend for themselves, whereas formerly, the SEC took a more active role on their behalf.

\section{Distribution to Other Affected Parties}

The experience of stockholders and bondholders is only one part of the collapse of a company, often a relatively small part. Mortgage lenders, equipment financers, inventory financers, receivable financers, trade creditors, factors, employees, taxing authorities, pensioners, customers, landlords, tenants, warranty claimants, tort victims - the list goes on and on-all stand to profit from any enhancement of the value of troubled firms. Bradley and Rosenzweig make no effort to collect data on any of the other parties who might be affected by a bankruptcy filing. As they concede in their final footnote, they "have not addressed the impact of either Chapter 11 or our proposal on corporate constituencies other than stockholders and bondholders." 145 They speculate, however, that their analysis is equally applicable to these parties. ${ }^{146}$ Even if their arguments prove inapplicable to parties other than public securities holders, Bradley and Rosenzweig assert, there is no cause for alarm, since "it is by no means self-evident that the welfare of these constituencies is an appropriate concern for the law of corporate bankruptcy."147

Without pressing the point that the welfare of constituencies like the employees of a business and the community of which it is a part are appropriate objects of concern for bankruptcy law, this statement must still be considered remarkable. Bradley and Rosenzweig seem to have forgotten that the creditors of a business have interests that particularly deserve consideration in bankruptcy and that those interests are not co-extensive with those of public bondholders

143. Id.

144. From 1938 to 1983 , the SEC actively participated in bankruptcy cases in which there was a substantial public investor interest. Since December 1983, the SEC has followed a policy of waiting for a request from the bankruptcy judge or the U.S. Trustee for advice with respect to matters within the Commission's expertise. See Securities Regulation Briefs, supra note 74. Lopucki and Whitford observe that current SEC practices "reflect an even more limited involvement by the SEC than was necessarily contemplated when the policy statement was issued." Lopucki \& Whitford, supra note 1, at 192-93 n.178.

145. Bradley \& Rosenzweig, supra note 2 , at 1088-89 n.108.

146. Id.

147. Id. 
and stockholders. ${ }^{148} \mathrm{~A}$ voluminous literature has developed on the subject of the rival interests of shareholders and several different classes of creditors, but it receives no recognition in the Bradley and Rosenzweig study. ${ }^{149}$

Bradley and Rosenzweig excuse the narrowness of their focus by noting that it would be difficult to measure claims by constituents other than bondholders and shareholders because "they do not hold claims that trade in organized markets." ${ }^{150}$ In fact, careful research has been conducted to document the distributions received by a number of creditor classes, additional research that Bradley and Rosenzweig ignore. ${ }^{151}$ More to the point, the observation that it is too hard to measure the total value distributed to all interested parties when a business reorganizes or liquidates in bankruptcy, while data on the value received by public securities holders are easier to acquire, does not justify a research design that ignores most of what takes place in Chapter 11.

I am unaware of any comparative data on the distributions to all parties preand post-Code, but the data on distributions to creditors in the largest post-Code cases lend some credence to the idea that Chapter 11 is working to encourage creditor repayment ahead of payments to public security holders. In their study of the largest post-Code cases to confirm a plan, LoPucki and Whitford found that the Chapter 11 plans provided for $100 \%$ repayment of all claims in more than $25 \%$ of the cases. ${ }^{152}$ The relatively higher overall repayment rates in large Chapter 11 cases suggest that creditors reap sufficient benefits from a reorganization effort that this distribution of value cannot be ignored.

148. Nor is it possible to use the public bondholders as representative of the returns to all creditors. Not only do bondholders have different-and often hostile-interests from those of other creditor classes, the bond data presented in the Bradley and Rosenzweig study are too scanty to give much picture of what actually happens to them. While they study the effects of bankruptcy filings on share prices in 157 pre-Code and 162 post-Code cases, Bradley and Rosenzweig report that they based their bond analysis on 88 companies, id. at 1071, but the bond list they sent to the Yale Law Journal and to me lists 91 companies, 38 pre-Code and 53 post-Code filings. Letter from Michael Bradley to Elizabeth Warren (June 4, 1992) (on file with author). In fact, they collect complete bond data for only 21 pre-Code and 29 post-Code companies. Id. (calculated from information provided therein).

This means that for 236 cases- $73 \%$ of the cases they study-Bradley and Rosenzweig's conclusions about declining value in bankrupt companies is based exclusively on the effects of bankruptcy on shareholders. There is no way to determine how holders of public debt fared in nearly three-quarters of the bankruptcies Bradley and Rosenzweig studied.

149. For an example of research that takes seriously the question of allocation of value between shareholders and creditors, see LoPucki \& Whitford, supra note 1. This research also demonstrates persuasively that it is not possible to assume that all superior classes have been paid in full from the fact that lower classes receive some value. LoPucki and Whitford found, for example, that "the relative size of equity's recovery appeared to be not so much a product of the financial conditions of the company as it was a product of the quality and aggressiveness of equity's representation." Id. at 195. Their results show that equity participated in reorganizations even when it was clear to all parties that the company was insolvent and equity had no legal claim to any distribution. Id.

150. Bradley \& Rosenzweig, supra note 2, at 1056 n.44.

151. See infra note 167 and accompanying text.

152. LoPucki \& Whitford, supra note 1 , at 135,142 . In most instances these were not just paper recoveries; the distributions were made in stocks, bonds, and promissory notes that the creditors could sell for cash. Id. 


\section{B. Redistribution in the Perfect Markets Solution}

Bradley and Rosenzweig offer what they call a "perfect markets solution" as a substitute for Chapter $11 .{ }^{153}$ Under that solution, a creditor facing a possible default on its debt would be able to demand that equity cure the default by paying the debt immediately. If equity could not raise sufficient capital to pay on time, the system would proceed according to the principle of "automatic cancellation of residual claims in the event of default"154 - that is, if the lowest class of residual owners could not raise sufficient capital to pay on time, it would lose all claims to the assets of the business, and the next level of residual owners would be offered the chance to pay the debt or face a similar annihilation of their claims. The process would continue up the line, automatically eliminating entire classes of ownership and debt until either someone paid off the default or the creditor who had suffered the default became the residual owner. ${ }^{155}$ The solution would operate "immediately upon the firm's default"156 and it thereby would eliminate "the costs of reorganization itself (i.e., judicial resources and legal, accounting, and financial advisory fees)." ${ }^{\prime 157}$ Bradley and Rosenzweig claim that if their perfect markets solution were adopted, parties would effectively create an insolvency scheme by contract, according to which creditors would negotiate for repayment priorities vis-à-vis every other creditor. ${ }^{158}$ They fail, however, to reflect on the distributional consequences of their proposed scheme.

Eliminating Chapter 11 and substituting a contract-based priority system would obviously disadvantage claimants who have no contract. This means that those injured by a debtor, such as tort victims, discrimination and harassment complainants, or antitrust plaintiffs, would be left out of the scheme. It is not simply that these claimants have the lowest collection priorities when a business fails in a perfect markets world; rather, it is not clear that the perfect markets mechanism would permit them to enforce those rights at all. Consider the plight of claimants against Dalkon Shield manufacturer A.H. Robins, in a hypothetical situation in which Robins had defaulted on a senior debt obligation of $\$ 100$ million. Would the thousands of women who were injured by the Dalkon Shield receive phone calls requiring them to come up with a $\$ 100$ million dollar debt payment by sundown or face the loss of their claims? Would they perhaps have

153. Bradley \& Rosenzweig, supra note 2 , at 1053.

154. Id. at 1078 .

155. Id. at 1079 .

156. Id. at 1086 (emphasis in original).

157. Id.

158. Id. at 1084 n.94. Extensive provisions defining default would be included in every contract, so that creditors could monitor on-going business activities to make certain the business is not engaging in "asset sales, risky projects, and the like" as a means of meeting outstanding obligations. Id. at 1086-87. Apparently Bradley and Rosenzweig believe that the creditors could effectively discern and put a stop to every kind of machination that management, facing almost certain ouster immediately upon default, could attempt in an effort to save itself. 
a few days to decide or to talk with the other thousands of similarly situated women as they faced "automatic" termination of their rights to collect? Would they have any access to collective representation, a market in which to trade their collection rights, a means to value their different claims against Robins, or a method to distinguish those who wanted to pursue Robins from those who were willing to concede defeat?

A number of other creditors also suffer in the contract-only paradigm. Government collectors, for example, such as taxing authorities, the Pension Benefit Guaranty Fund, and the Environmental Protection Agency, are omitted from the Bradley and Rosenzweig discussion. Would they continue to enjoy priorities by operation of law? Would their priorities be superior to contract priorities? Would nongovernmental claimants with collection priorities, such as material-men and mechanics, enjoy priorities ahead of or behind contract and government priorities? Would we simply recreate a bankruptcy priority scheme through nonbankruptcy law? ? $^{159}$

Even among contract-based claimants, some classes would persistently win out over others. Can rank-and-file employees be expected to negotiate for stronger repayment rights more effectively than commercial lenders? Can pensioners be expected to bargain for collection rights ahead of public bondholders? Can trade creditors be expected to collect on a par with secured creditors? A contract-based scheme is overtly distributional in a regressive sense; it redistributes wealth away from those parties currently receiving - and who deserve to receive-protection under the Code.

The parties who have been left out of the perfect markets solution serve as a reminder that a key goal of bankruptcy is to determine precisely what Bradley and Rosenzweig claim will be obvious in the parties' contracts: the relative priorities of the collecting parties. Currently, priorities are established by a combination of contract and the operation of law. To change to a priority system determined entirely by contract would involve a significant reordering of the rights of many who are owed obligations by large corporations.

Bradley and Rosenzweig summarize their research as follows: "Chapter 11 allows, indeed, encourages, managers to place their interests ahead of the interests of their security holders and to take actions that they could not take without court protection from creditor scrutiny."160 It would be more accurate to say that Chapter 11 allows, indeed, encourages, managers to place the interests of creditors, employees, taxing authorities, tort victims, pensioners, warranty

159. Bradley and Rosenzweig propose to repeal the laws of bankruptcy. To make their priority-by-contract scheme work, however, they would also have to repeal state collection laws in corporate law cases. Otherwise, an unsecured creditor could presumably jump higher in the collection order by getting a state law judgment lien. Similarly, UCC security interests would also presumably have to be suspended in corporate law cases, since any creditor planning to exercise its rights of repossession would be circumventing the priority-bycontract order by satisfying its debt without either paying off senior debt or having its interests wiped out.

160. Id. at 1076. 
claimants, and a host of other parties ahead of those of the public security holders, and to apportion the remaining value of a troubled firm among a number of interested parties rather than distributing a disproportionate share to a single group.

\section{Comparing Costs of Bankruptcy and "Perfect Markets"}

Bradley and Rosenzweig defend their perfect markets solution as a costeffective alternative to the current bankruptcy scheme. Even if their data do not support eliminating Chapter 11 on the grounds that the system reduces overall value for other reasons, a system that reduces overall costs is value-preserving in its own right. When overall costs are lowered, there is more value to distribute to parties injured by a business failure. A brief look at the perfect markets solution will reveal its promise for lowering the costs of business failure.

Bradley and Rosenzweig describe their proposal as an "extreme version of a 'market based' solution to corporate bankruptcy,"161 noting that their perfect markets solution works in a perfect world. But what happens in an imperfect world? Here, Bradley and Rosenzweig make an interesting concession:

The relevance or applicability of the perfect markets solution to the real world depends on the efficiency of the pertinent real-world markets. Specifically, if the labor market, the capital market, the market for information, and the market for corporate control are efficient, then there is no economic justification for [bankruptcy]. Judicial intervention is warranted only if there are significant information asymmetries, transactions costs, or ambiguous property rights. ${ }^{162}$

Unfortunately, we live in an imperfect world. Economists have long recognized that solutions proposed for perfect markets may not work in imperfect markets. Using a theory of the second best, economists note that a device that works well within the constraints of a perfect market may, in fact, aggravate, rather than solve, problems in an imperfect market. ${ }^{163}$

If we had perfect markets, Bradley and Rosenzweig might be right that we would have no need for Chapter 11. But if we had perfect markets with perfect information, perfectly understood and undisputed property rights, and zero transaction costs, it is not clear that we would have defaults or business failures. The thought experiment is intriguing. Would a radio manufacturer in Boston with perfect information in a frictionless market adjust to the declining demand for radios and the increasing demand for housing in Minneapolis by changing its production output and location, always returning a market rate on its capital

161. Id. at 1050 .

162. Id. at 1054 .

163. See R.G. Lipsey \& Kelvin Lancaster, The General Theory of Second Best, 24 REV. ECON. STUD. 11 (1956). 
investments? Would workers who perfectly anticipated the decline in domestic protection of steel that would cost them their jobs in Akron move immediately and costlessly to San Antonio where they could fill the demand for chefs in Mexican restaurants? Would perfectly informed shipbuilders in the 1940's breathe asbestos, develop asbestosis in the 1980's, and recover money without any costs to determine liability from the perfectly informed asbestos manufacturer who had included these costs in the calculation of production output for fifty years? In the perfect market that Bradley and Rosenzweig propose, many of the business failures that plague our economy would disappear. There would be little need for Chapter 11 because there would be little failure-just cost-free redeployment of assets.

There is thus a curious asymmetry in Bradley and Rosenzweig's proposal: they assume a sufficiently imperfect market for businesses to fail, but a sufficiently perfect market for their "extreme version of a 'market based' solution"164 to be effective in dealing with those failures. I have difficulty envisioning that market.

Bradley and Rosenzweig argue that bankruptcy is justifiable only if there are problems generated by "significant information asymmetries, transactions costs, or ambiguous property rights." ${ }^{\text {.165 }}$ In my view, Chapter 11 was specifically designed to respond to such problems. Chapter 11 creates the conditions for collective creditor action, reducing the costs of individual creditor collection activities. It provides an opportunity for collective supervision, supported by the power of the court, to ensure that assets remain in place, that only ordinary business transactions occur, and that additional financing agreements and contract obligations are undertaken only after notice to the creditors and a hearing before the court. It imposes extensive disclosure obligations on the debtor, so that creditors can monitor the debtor and make more informed decisions than they could if the debtor were not in bankruptcy. Chapter 11 also reduces the ability of a single, secured creditor to impose losses on others by precipitous closure of a viable business through repossession. It reduces the ability of a single creditor to demand a premium in the renegotiation of the financial structure of a troubled debtor. It provides a speedier, low-cost alternative to state courts for resolving contract and other legal disputes, employing a number of procedures to keep the cost of claims estimation low. It provides a forum for negotiating deals, and, ultimately, it allocates the value of a firm to all claimants, making difficult distributional decisions among competing parties. All of these functions help to reduce transaction costs, correct information asymmetries, and resolve legal disputes that exist in the real world between a troubled company and the thousands of entities with which it conducts its business.

164. Bradley \& Rosenzweig, supra note 2 , at 1050.

165. Id. at 1054. 
Bradley and Rosenzweig's claim that their perfect markets solution is more efficient because it involves a substantial bankruptcy cost savings ${ }^{166}$ cannot be maintained in the absence of a serious attempt to answer two empirical questions: first, how high are the costs of the current Chapter 11 system?, and second, would a substitute system without Chapter 11 be less costly?

There is little evidence about the direct costs of a Chapter 11 bankruptcy, but the few studies that exist suggest that the costs of Chapter 11 are relatively modest. Most estimates place the costs at $1 \%$ to $3 \%$ of the net worth of the business, although one study put the combined direct and indirect costs at $11 \%$ to $17 \% .{ }^{167}$ An historical point also bears on the issue: Reorganization has existed in one form or another for almost as long as large corporate entities have failed. ${ }^{168}$ Both factors lead me to agree with Judge Easterbrook when he says that bankruptcy reorganization probably survives because it is the lowest-cost method of dealing with business failure. ${ }^{169}$

Would the perfect markets solution be less costly? The difficulty of implementing it is illustrated by considering the following example. After its 1988 merger with Campeau Corporation, Federated Department Stores and its sixty-six affiliates and subsidiaries filed for Chapter 11 on January $15,1990 .{ }^{170}$ During the course of the reorganization, the court resolved disputes over contractual priority, statutory priority, equitable priority, intracorporate guarantees, fraudulent conveyances, indemnity agreements, obligations from executory contracts,

166. Id. at 1085 .

167. Bradley and Rosenzweig infer the costs of bankruptcy by examining only the relative values of publicly traded stocks and bonds. There are a number of other financial data they might have examined to determine those costs. Researchers have produced careful work calculating the direct costs of bankruptcy on the overall value of a firm, which would seem to offer a better measure of the protection of value provided by a bankruptcy proceeding than would an examination of what the shareholders can keep after a reorganization. See, e.g., Edward I. Altman, A Further Empirical Investigation of the Bankruptcy Cost Question, 39 J. FIN. 1067, 1087 (1984) (study of 19 firms filing for bankruptcy pre-Code and 7 post-Code estimated direct and indirect costs at 11 to 17\%); Theodore Eisenberg, Bankruptcy in the Administrative State, 50 LAW \& CONTEMP. PROBS. 3, 42 n. 177 (estimating direct costs in bankruptcy at $1 \%$ to $3 \%$ of assets); Jerold B. Wamer, Bankruptcy Costs: Some Evidence, 32 J. FIN. 337, 339 n.5 (1977) (estimating direct costs in pre-Code reorganizations of 11 railroads about $1 \%$ of market value of firm). Lawrence A. Weiss, Bankruptcy Resolution: Direct Costs and Violation of Priority Claims, J. FIN. ECON. 285, 286, 289, 291 (1990) (estimating costs of large bankruptcies at about $3.1 \%$ of assets based on analysis of 37 publicly traded firms filing for bankruptcy between November 1979 and December 1986); Michelle J. White, The Behavior of Firms in Financial Distress, 28 J. FIN. 477, 484, 486 (1983) (estimating $1.3 \%$ ex ante costs of bankruptcy and $2 \%$ to $4 \%$ ex post costs based on study of 186 pre-Code firms and 121 post-Code firms).

It would, of course, be desirable to compare what the costs of out-of-court debt restructuring would be in the absence of bankruptcy with bankruptcy restructuring costs, in order to determine whether overall costs would be reduced by the elimination of Chapter 11. But out-of-court restructuring occurs in the shadow of bankruptcy, and thus no such comparison is possible. See WARREN \& WESTBROOK, DEBTORS AND CREDITORS, supra note 62 , at $433-35,622-40$.

168. For an interesting discussion of the history of pre-bankruptcy receiverships and a comparison with modern bankruptcy reorganizations, see Eisenberg, supra note 120, at 4-20.

169. Frank Easterbrook, Is Corporate Bankruptcy Efficient?, 27 J. FIN. ECoN. 411, 413-14 (1990) (Laws "endure either because they are efficient or because they redistribute wealth to concentrated, politically effective interest groups," which he concludes do not exist in bankruptcy.).

170. Disclosure Statement of Federated Department Stores, Inc., Allied Stores Corporation, and Certain of Their Subsidiaries, In re Federated Dep't Stores, Inc., 133 B.R. 886 (Bankr. S.D. Ohio 1991). 
unexpired leases, pension plan liability, and a number of tax complications ${ }^{171}$-all of which presumably would persist in the perfect markets environment. Federated's 45,000 creditors were grouped into seventy-seven identified classes of debt. Even granting a number of improbable assumptions- that there were no disputes over the complex corporate arrangements of Federated's sixtysix affiliates, no disputes over who owed what to whom, no disputes over the priority of each debt relative to the debts of other creditors, and that members of each class got one month (and no longer) to receive information about the pay-or-lose proposition they faced, to make an informed choice, to vote their interests, and to come up with the money if they chose to pay-Bradley and Rosenzweig's "automatic" perfect markets solution would not be automatic. It would have taken six years and four months for the senior creditors to become the owner of the company if the other creditors refused the payment demand. ${ }^{172}$ Federated, by contrast, confirmed its plan in twenty-six months, paying twentyfour classes $100 \%$ of their outstanding claims, and reorganizing itself into fourteen operating units employing 80,000 people nationwide. In the months following the confirmation of its plan, it sold forty-six million shares of common stock netting $\$ 500$ million, which it used to pre-pay $\$ 950$ million of debt. ${ }^{173}$ In June of 1992, bond services upgraded the ratings of Federated debt, ${ }^{174}$ and Federated stock remains actively traded on the New York Stock Exchange today. ${ }^{175}$

The perfect markets solution may work in a perfect market, where it is unlikely ever to be needed. But in the markets in which business failures occur, there is no evidence that the costs would be lower or that the system would be fairer than the current Chapter 11 system.

\section{CONCLUSION}

After twelve years of experience with the new Bankruptcy Code, people are angry with the bankruptcy process. Creditors are angry with debtors who have resisted payment and thwarted their collection efforts. Employees are angry with companies that have laid them off while the big boys remain in their high paying jobs. Tort victims are angry with companies because they are not getting

171. Id.

172. 76 classes $\times 1$ month per class $=6$ years and 4 months. Bradley and Rosenzweig do not discuss the mechanisms for dealing with disparate creditors in a single class. Would they each have a proportional option? What would happen if some in each class wanted to cure the default while others did not? Would the remaining creditors be forced to pay more or lose out? Or in a perfect market would none of these complications occur?

173. Jeffery A. Trachtenberg, Corporate Focus: Federated, Rising From the Ashes, Still Faces Hurdles, WALL ST. J., June 22, 1992, at B3.

174. Id. Both Moody's Investors Service and Standard \& Poor's upgraded the retailer's debt issues in June, 1992.

175. The successful Federated bankruptcy was not included in the Bradley and Rosenzweig sample, even though less successful cases filed after Federated were included. See supra note 87. 
enough money to compensate them for all that they have lost. Judges are angry with disputants because they have neither the time nor the resources to monitor the cases in their care. And everyone is angry with the lawyers because they are getting rich.

The bankruptcy system also attracts criticism because it is the place where problems are aired. Many intractable economic and social problems-declining industries, staggering environmental liabilities, underfunded pension plans, mass torts, increased international competition, inadequate medical insurance, and more-are dumped into the bankruptcy system for resolution. Even if bankruptcy provides the best available opportunity to solve these problems, it is the system's failure to provide perfect solutions that captures the greatest attention. In this climate of anger, it is easy for Bradley and Rosenzweig to call for the abolition of Chapter 11. No one likes the system, except perhaps the attorneys who feed off it. ${ }^{176}$

So why not repeal Chapter 11 ? Because thus far, no one has come up with a good substitute. By the time we invent a system that establishes priorities among creditors, supervises defaulting debtors, provides notice and a hearing to creditors whose rights need to be determined, preserves going-concern value, and provides a collective forum to determine the rights of multiple parties, we have created another reorganization system. The details may differ, and reasonable people may disagree about what those details ought to be. We may call the system something other than "Chapter 11." There remains, however, a compelling need for some centralized procedure to deal with business failure.

Many of the people who are angry with the bankruptcy system are angry because they have not received what they had every right to expect: payment on time, a safe working environment, a steady job at a fair wage, and a management team that made thoughtful decisions and brought prosperity to the business. Those problems, however, are not bankruptcy problems. They are the problems of bad management, bad guesses, and bad luck. They are also the consequences of those information asymmetries, transaction costs, and uncertain legal rights that exist in imperfect worlds.

The bankruptcy system matters. It mattered to a $\$ 10$ billion business like Federated, and it mattered to their 80,000 employees who stayed on the job. The system also matters to every borrower, lender, potential victim, and warranty claimant, as well as to every person who may some day have to consider the consequences of nonpayment of a debt she owes or is owed. Changes in distributional rights, in the costs of bankruptcy operations, and in the powers given to judges and trustees to supervise bankruptcy administration affect all debtors and claimants, whether the debtor is currently in bankruptcy or not.

Facts also matter. They have a powerful virtue: once they are known, policy makers and academics alike must adjust their arguments to accommodate them.

176. Bradley \& Rosenzweig, supra note 2, at 1049; N.Y. TMMES FORUM, supra note 44. 
Credible empirical data, more than anything else scholars bring to the table, can drastically change the terms of a debate. Bankruptcy policymaking should proceed with as much factual information as possible. There are few areas in which the expenditure of resources to understand and to improve the operation of the system could have more far-reaching consequences. But all those potentially affected by the system have a right to demand that the debates proceed on the basis of reliable information. Because empirical research is extraordinarily difficult to review, the researcher bears a unique burden to conduct the work with care and to present the results cautiously and accurately. The data produced by Bradley and Rosenzweig are unsound, too unsound to earn a place in the Chapter 11 debate. 
